\title{
2,3-Dihydropyridin-4(1H)-ones and 3-Aminocyclohex-2-enones: Synthesis, Functionalization, and Applications to Alkaloid Synthesis
}

\author{
Hajime Seki, Gunda I. Georg* \\ Departments of Chemistry and Medicinal Chemistry, and the Institute for Therapeutics Discovery and Development, College of Pharmacy, \\ University of Minnesota, 717 Delaware Street SE, Minneapolis, MN 55414, USA \\ Fax+1(612)6266318; E-mail: georg@umn.edu
}

Received: 13.03.2014; Accepted after revision: 23.06.2014

License terms: (c)

Abstract: This account summarizes our recent investigations into the chemistry of 2,3-dihydropyridin-4(1H)-ones and 3-aminocyclohex-2-enones (enaminones). These enaminones are exceptionally versatile chemical scaffolds that serve as valuable intermediates in the synthesis of indolizidine and quinolizidine alkaloids and other bioactive compounds. Since we reported our first method for constructing enaminones in 2006, we have developed a number of additional approaches to the synthesis and derivatization of enaminones and we have explored their applications in natural product synthesis.

1 Background

2 Ynone Cyclization

2.1 Initial Discovery

2.2 Optimization of Reaction Conditions

2.3 Scope and Limitations

2.4 Mechanistic Studies

2.4 Application to Quinolone Synthesis

$2.6 \quad N$-Butoxycarbonyl $\beta$-Lactam Approach

2.7 Synthesis of 3,4-Dihydro-1,2-oxazepin-5(2H)-ones and Their Conversion into Enaminones

3 Ketene Cyclization

3.1 Chiral-Pool Approach

3.2 Three-Component Synthesis

4 C5 Functionalization

4.1 Suzuki Coupling of Iodoenaminones

4.2 Suzuki-Type Direct Cross-Coupling

4.3 Suzuki-Type Direct Cross-Coupling with Arylboronic Acids

4.4 Hiyama-Type Direct Cross-Coupling

4.5 Direct Coupling with Aryl Iodides

4.6 Alkenylation by the Fujiwara-Moritani Reaction

4.7 Alkenylation of Uracils

4.8 Aerobic Alkenylation and its Application to the Synthesis of 1,3,5-Trisubstituted Benzenes

4.9 Lithium Perchlorate-Catalyzed Alkylation

5 Applications to Total Synthesis

5.1 Total Synthesis of $(+)$-Ipalbidine and (+)-Antofine

5.2 Total Synthesis of $(R)$ - and $(S)$-Boehmeriasin A

5.3 Total Synthesis of Tylocrebrine and Related Phenanthropiperidines

$6 \quad$ Summary and Outlook

Key words: heterocycles, enaminones, alkaloids, natural product synthesis

SYNLETT 2014, 25, 2536-2557

Advanced online publication: 24.09 .2014

DOI: 10.1055/s-0034-1378529; Art ID: st-2014-a0221-a

(C) Georg Thieme Verlag Stuttgart · New York

\section{Background}

Because indolizidine, piperidine, and quinolizidine alkaloids often possess biologically interesting properties, the synthesis community has devoted significant efforts to preparing and investigating those alkaloids. ${ }^{1,2}$ In this regard, cyclic enaminones such as 2,3-dihydropyridin4(1H)-ones 1.3 have been shown to be excellent intermediates for the synthesis of indolizidine, piperidine, and quinolizidine alkaloids (Scheme 1). ${ }^{3,4}$

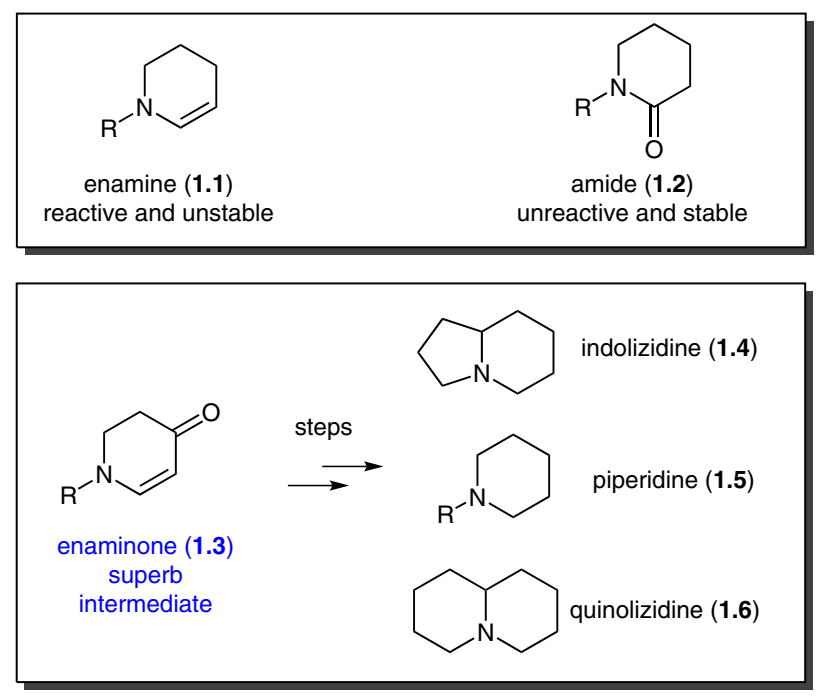

Scheme 1 Overview of enaminones

The chemical properties of enaminones are quite different from those of enamines 1.1 or amides 1.2. Enamines, which are neutral nucleophiles, have been used in a number of reactions, ${ }^{5,6}$ although they can be quite unstable under hydrolytic or oxidative conditions. On the other hand, the amide group is a stable functional group and amides can be easily isolated. Because of this stability, very strong reagents are typically required to functionalize amides. The reactivities and stabilities of enaminones lie between those of enamines and amides. Under hydrolytic and oxidative conditions, enaminones are generally more stable than enamines, but they maintain a certain degree of nucleophilicity that clearly differentiates them from amides. These stable but reactive properties are what make enaminones useful as intermediates for the synthesis of alkaloids. 
A number of transformations of enaminones are known (Scheme 2). The C3 position can be functionalized by enolate chemistry to give derivatives $\mathbf{1 . 7} .^{7,8}$ Nucleophilic additions of soft nucleophiles such as cuprates take place at the $\mathrm{C} 6$ position to give products 1.9. ${ }^{8,9}$ Functionalization at the $\mathrm{C} 5$ position to give products $\mathbf{1 . 8}$ has been extensively studied; for example, halogenated derivatives have been used in palladium-catalyzed cross-coupling reactions. ${ }^{10,11}$ Triflation has been practiced in two different ways either directly from the enaminones $\mathbf{1 . 3}$ to give the triflates $\mathbf{1 . 1 1}$ or sequentially after double-bond reduction to form triflates $\mathbf{1 . 1 0} .^{12-14}$

\section{$2 \quad$ Ynone Cyclization}

\subsection{Initial Discovery}

We initially attempted to synthesize enaminones by cyclizing the amino ynone $\mathbf{2 . 3}$ in a 6-endo-dig fashion (Scheme 3). ${ }^{15}$ Although intermolecular Michael addition to ynones is well known, the intramolecular variant had

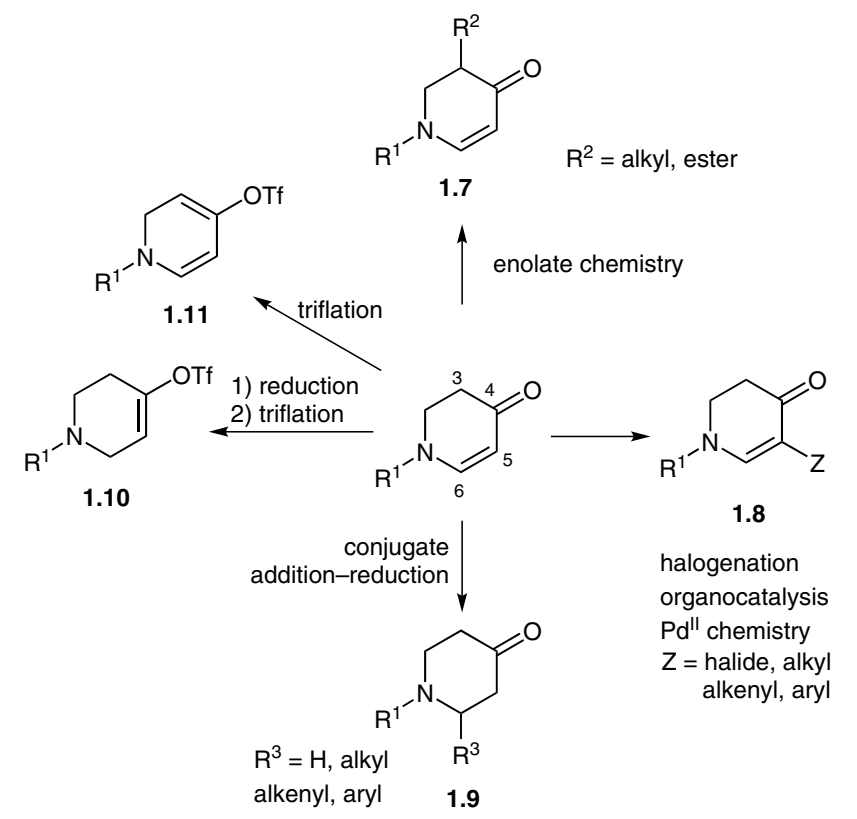

Scheme 2 Selected transformations of enaminones not been reported, even though cyclization should be a fa-

\section{Biographical Sketches}
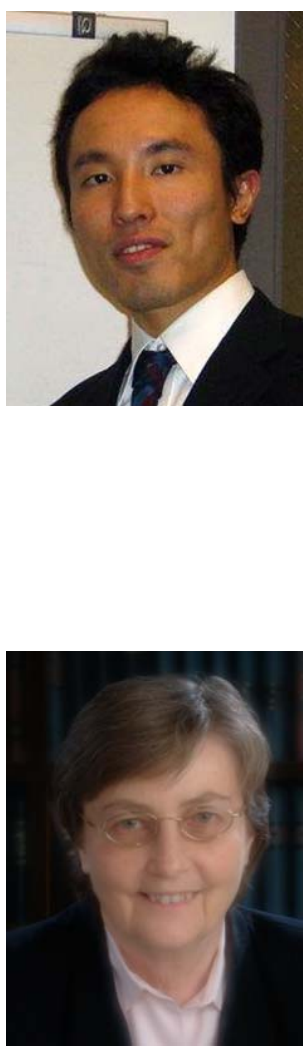

Dr. Hajime Seki was born in Kawasaki, Japan, in 1983. In 2005, he received his B.S. degree from Keio University, Japan, where he studied ruthenium-catalyzed $\mathrm{C}-\mathrm{H}$ activation chemistry under the guidance of Professor Fumitoshi Kakiuchi. Soon after, he entered graduate school at Keio University before moving to the U.S.A. and joining the

Professor Gunda I. Georg was born in Herborn in the state of Hesse, Germany. She received a degree in pharmacy in 1975 and a Dr. rer. nat. degree in medicinal chemistry in 1980 from the Philipps University of Marburg in Germany under the direction of Professor Manfred Haake. After postdoctoral studies at the University of Marburg and in the Department of Chemistry at the University of Ottawa, Canada, in the labo- chemistry Ph.D. program at the University of Minnesota. In 2011, he obtained his Ph.D., directed by Professor Gunda I. Georg. For his Ph.D. studies, he worked on the development of new methodologies, alkaloid synthesis, and the construction of libraries of anticancer agents, some of which are covered in this review. Since May 2012, he has

ratory of Professor Tony Durst, she accepted a oneyear post as assistant professor at the University of Rhode Island. She then moved to the University of Kansas in 1984 to become a faculty member in the Department of Medicinal Chemistry in the School of Pharmacy. In 2007, she moved to the Department of Medicinal Chemistry in the College of Pharmacy at the University of Minnesota. She is currently head of the continued his academic career as a research associate in the laboratory of Professor Kim D. Janda at the Scripps Research Institute, where he develops and evaluates inhibitors for the zinc protease of botulinum neurotoxin A. Inside the lab, he enjoys chemical biology, and outside, he enjoys nice weather and badminton.

department and is the founding director of the Institute for Therapeutics Discovery and Development. She holds the Vince and McKnight Endowed Chairs. She has published 200 scientific contributions in organic and medicinal chemistry, and has trained 100 students, fellows, and scientists in her laboratory. She is currently co-editorin-chief of the Journal of Medicinal Chemistry. 
vorable transformation according to Baldwin's rules. The investigation started by synthesizing the quinolizidine system 2.4. $N$-(tert-Butoxycarbonyl)pipecolic acid (2.1) was converted into the homologated Weinreb amide $\mathbf{2 . 2}$ by a Wolff rearrangement. This amide was reacted with an ethynyl Grignard reagent to give the $N$-tert-butoxycarbonylamino ynone 2.3. When we screened conditions for deprotection of the tert-butoxycarbonyl group and subsequent cyclization we found that the desired quinolizidine system 2.4 was obtained by treating the ynone with hydrochloric acid or iodo(trimethyl)silane, followed by potassium carbonate in methanol. ${ }^{16}$<smiles>CC(C)(C)OC(=O)N1CCCC[C@H]1C(=O)O</smiles>

2.1

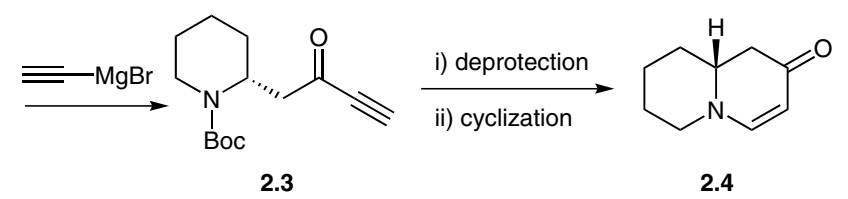

\begin{tabular}{lll} 
i) deprotection & ii) cyclization & yield (\%) \\
\hline TFA, CH $\mathrm{Cl}_{2}$ & $\mathrm{CH}_{2} \mathrm{Cl}_{2}, \mathrm{aq} \mathrm{NaHCO}_{3}$ & 30 \\
$4 \mathrm{~N} \mathrm{HCl} /$ dioxane & $\mathrm{CH}_{2} \mathrm{Cl}_{2}, \mathrm{H}_{2} \mathrm{O}, \mathrm{NaHCO}_{3}$ & 74 \\
$4 \mathrm{~N} \mathrm{HCl} /$ dioxane $_{\mathrm{N}}$ & ${\mathrm{MeOH}, \mathrm{K}_{2} \mathrm{CO}_{3}}^{\mathrm{MeOH}, \mathrm{K}_{2} \mathrm{CO}_{3}}$ & 87 \\
$\mathrm{TMSI}, \mathrm{CH}_{2} \mathrm{Cl}_{2}$ & $\mathrm{MeOH}$ & 95
\end{tabular}

Scheme 3 Protocol for forming enaminone $\mathbf{2 . 4}$ from the $N$-tertbutoxycarbonylamino ynone $\mathbf{2 . 3}$ at room temperature

Chiral HPLC analysis revealed that the enantiomeric ratio of the product was 97:3 when hydrochloric acid was used for the deprotection. Because deprotection with trifluoroacetic acid gave only modest yields, if any, we concluded

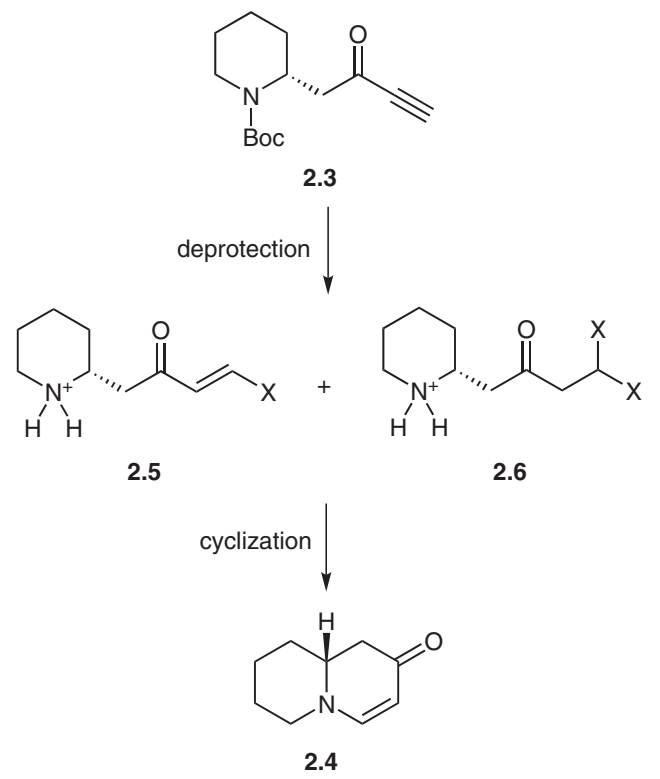

Scheme 4 Proposed mechanism of ynone cyclization that halides must play an important role in this reaction. We therefore proposed a mechanism involving halide activation (Scheme 4). We posited that under the deprotection conditions, cationic vinylogous acid halide $\mathbf{2 . 5}$ and dihalogenated $\mathbf{2 . 6}$ form as intermediates, possibly preventing intermolecular reactions.

When the scope of this method was investigated, however, significant racemization was observed in some cases (Figure 1). For example, the enaminones $\mathbf{2 . 7}$ and 2.8, derived from hydroxyproline, racemized during the cyclization, to give diastereomeric ratios of $80: 20$ and $86: 14$, respectively. ${ }^{15}$ Because proline-derived enaminones are useful as indolizidine scaffolds, this racemization might jeopardize the usefulness of the chiral-pool approach.

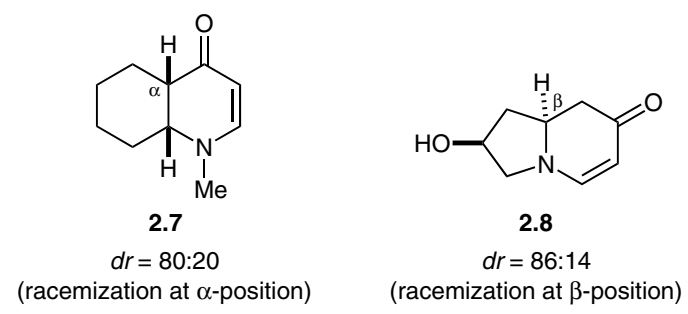

Figure 1 Racemized enaminones $\mathbf{2 . 7}(\mathrm{HCl}, 1,4$-dioxane) and $\mathbf{2 . 8}$ (TMSI)

\subsection{Optimization of Reaction Conditions}

Given the short duration of the cyclization reaction, racemization is likely to have occurred during the tert-butoxycarbonyl deprotection step. Because racemization was observed at the $\alpha$ - and $\beta$-positions in ynones $\mathbf{2 . 1 0}$, two different pathways were proposed (Scheme 5). ${ }^{16}$

One possible mechanism is a retro-Mannich reaction that cleaves the $\mathrm{C}-\mathrm{C}$ bond and racemizes the $\alpha$-stereocenter. The other path is a retro-Michael reaction that cleaves the $\mathrm{C}-\mathrm{N}$ bond and racemizes the $\beta$-stereocenter. On the assumption that strong acidity in the deprotection step is responsible for these racemizations, several acids were screened (Table 1). ${ }^{16}$ A combination of formic acid as a weak acid and sodium iodide as an external source of halide was found to be optimal for the reaction. Under these conditions, racemization was minimized, and the enantio-<smiles>[R]NC([R])C([R])C(=O)C#C</smiles><smiles>[R]C=N[R]</smiles>

2.9<smiles>[R]/C=C(/[R])C(=O)C#C</smiles><smiles>[R]NC([R7])C([R7])C(=O)C#C</smiles>

Scheme 5 Mechanisms of racemization of enaminones 
merically enriched enaminone $\mathbf{2 . 1 2}$ was obtained in $>95: 5$ er.

Table 1 Optimization of Cyclization Step ${ }^{16}$

$\mathrm{HO}$<smiles>C#CC(=O)CC1C[C@@H](C)CN1C(=O)OCc1ccccc1</smiles>

\begin{tabular}{|c|c|c|}
\hline 2.11 & \multicolumn{2}{|c|}{2.12} \\
\hline Reaction conditions & Yield $(\%)$ & er \\
\hline $\mathrm{N} \mathrm{HCl}-1,4$-dioxane & 77 & $85: 15$ \\
\hline TFA & 31 & $67: 33$ \\
\hline$\Gamma \mathrm{FA}-\mathrm{CH}_{2} \mathrm{Cl}_{2}(1: 1)$ & 18 & $88: 12$ \\
\hline $\mathrm{N} \mathrm{HCl}, \mathrm{Et}_{2} \mathrm{O}$ & 36 & $67: 33$ \\
\hline TESOTf, 2,6-lutidine, $\mathrm{CH}_{2} \mathrm{Cl}_{2}$ & 21 & $83: 17$ \\
\hline TMSI ( 3 equiv), $\mathrm{CH}_{2} \mathrm{Cl}_{2}$ & 99 & $75: 25$ \\
\hline $\mathrm{HCO}_{2} \mathrm{H}$, r.t. & 0 & - \\
\hline $\mathrm{NaI}$ (3 equiv), $\mathrm{HCO}_{2} \mathrm{H}$, r.t. & 93 & $>95: 5$ \\
\hline
\end{tabular}

\subsection{Scope and Limitations}

Two series of bicyclic and monocyclic enaminones were prepared by using the optimized protocol (Tables 2 and 3, respectively). ${ }^{16}$

Table 2 Substrate Scope for Bicyclic Enaminones ${ }^{16}$

\begin{tabular}{lll}
\hline Product & R & Method $^{\mathrm{a}} \begin{array}{l}\text { Yield }^{\mathrm{b}} \mathrm{er}^{\mathrm{c}} \text { or drd } \\
(\%)\end{array}$
\end{tabular}

\begin{tabular}{ccccc}
\hline & & A & 87 & $97: 3$ \\
H (2.13) & B & 90 & $>98: 2$
\end{tabular}<smiles>P=C1C=C(P)N2CCCCC2C1</smiles>

$\operatorname{Me}(\mathbf{2 . 1 4})$

A $\quad 87 \quad 73: 27$

$\mathrm{Ph}(\mathbf{2 . 1 5})$

$\mathrm{B}$

B $\quad 80$

$73: 27$

A $\quad 91 \quad 58: 42$

B 85

69:31<smiles>O=C1C=C(P)N2CCCC2C1</smiles>

H (2.16)

A $\quad 89$

$70: 30$

$\begin{array}{lll}\text { B } & 96 & 98: 2\end{array}$

$\mathrm{BnO}$<smiles>O=C1C=C(P)N2CCCC2C1</smiles>

$\operatorname{Me~(2.20)~}$

Me (2.17) A $\quad 87$

$\mathrm{Ph}(\mathbf{2 . 1 8})$

A

89

H (2.19)

A 94

B

$67: 33$

$>95: 5$

A $\quad 87$

$63: 37$

B 94

$68: 32$

A $\quad 85$

B $\quad 88$
Table 2 Substrate Scope for Bicyclic Enaminones ${ }^{16}$ (continued)

\begin{tabular}{|c|c|c|c|c|}
\hline Product & $\mathrm{R}$ & Method $^{\mathrm{a}}$ & $\begin{array}{l}\text { Yield }^{\mathrm{b}} \\
(\%)\end{array}$ & $e r^{c}$ or $d^{d}$ \\
\hline & \multirow{3}{*}{$\alpha-\mathrm{OH}(\mathbf{2 . 1 2})$} & A & 77 & $85: 15$ \\
\hline & & B & 93 & $>95: 5$ \\
\hline & & $\mathrm{C}$ & 94 & $96: 4$ \\
\hline & \multirow{3}{*}{$\beta-\mathrm{OH}(\mathbf{2 . 8})$} & A & 60 & $60: 40$ \\
\hline & & B & 95 & $92: 8$ \\
\hline & & $\mathrm{C}$ & 70 & $86: 14$ \\
\hline & \multirow{2}{*}{$(2.22)$} & A & 80 & \\
\hline & & B & 95 & \\
\hline & \multirow{3}{*}{$c i s-(\mathbf{2 . 7})$} & A & 96 & $80: 20$ \\
\hline & & B & 83 & $94: 6$ \\
\hline & & $\mathrm{C}$ & 80 & $67: 33$ \\
\hline & \multirow{2}{*}{ trans $-(\mathbf{2 . 2 3})$} & A & 99 & $>95: 5$ \\
\hline & & B & 82 & $>95: 5$ \\
\hline
\end{tabular}

${ }^{a}$ Method A: (i) $4 \mathrm{~N} \mathrm{HCl}$-1,4-dioxane, 15 min, (ii) $\mathrm{K}_{2} \mathrm{CO}_{3}, \mathrm{MeOH}$; Method B: (i) NaI (3 equiv), $\mathrm{HCO}_{2} \mathrm{H}, 6-24 \mathrm{~h}$, (ii) $\mathrm{K}_{2} \mathrm{CO}_{3}, \mathrm{MeOH}$; Method C: (i) TMSI, $\mathrm{CH}_{2} \mathrm{Cl}_{2}$, (ii) $\mathrm{K}_{2} \mathrm{CO}_{3}, \mathrm{MeOH}$.

${ }^{\mathrm{b}}$ Isolated yield.

${ }^{\mathrm{c}}$ Determined by HPLC.

${ }^{\mathrm{d}}$ Determined by ${ }^{1} \mathrm{H}$ NMR spectroscopy.

Table 3 Substrate Scope for Monocyclic Enaminones ${ }^{16}$

\begin{tabular}{|c|c|c|c|c|}
\hline Product & $\mathrm{R}$ & Method $^{\mathrm{a}}$ & Yield $^{\mathrm{b}}(\%)$ & $\mathrm{er}^{\mathrm{c}}$ \\
\hline & & A & 50 & $>99: 1$ \\
\hline & $(2.24)$ & B & 50 & $>99: 1$ \\
\hline & H (2.25) & A & 92 & $>95: 5$ \\
\hline & $\operatorname{Me}(\mathbf{2 . 2 6})$ & A & 96 & $>95: 5$ \\
\hline
\end{tabular}

\begin{tabular}{llll}
$\mathrm{H}(\mathbf{2 . 2 7})$ & $\mathrm{A}$ & 70 \\
& & $\mathrm{~B}$ & 92 \\
& $\mathrm{CH}_{2} \mathrm{Ph}(\mathbf{2 . 2 8})$ & $\mathrm{A}$ & 50 \\
\hline & & $\mathrm{B}$ & 86 \\
$\mathrm{R}$ & $\mathrm{Ph}(\mathbf{2 . 2 9})$ & $\mathrm{A}$ & 50 \\
& $\mathrm{~B}$ & 70 \\
\hline
\end{tabular}

${ }^{a}$ Method A: (i) $4 \mathrm{~N} \mathrm{HCl}$-1,4-dioxane, 15 min, (ii) $\mathrm{K}_{2} \mathrm{CO}_{3}$, $\mathrm{MeOH}$, r.t.; Method B: (i) $\mathrm{NaI}$ (3 equiv), $\mathrm{HCO}_{2}$, r.t., 6-24 h, (ii) $\mathrm{K}_{2} \mathrm{CO}_{3}, \mathrm{MeOH}$, r.t.

${ }^{\mathrm{b}}$ Isolated yield.

${ }^{c}$ Determined by HPLC. 
The use of formic acid and sodium iodide markedly suppressed the racemization in most cases; however, these conditions were ineffective for the cyclization of substituted ynones, leading to $\beta$-racemization in products $\mathbf{2 . 2 0}$ and 2.21. The strategy also allowed the synthesis of several seven-membered enaminones (Scheme 6). Although the expected decrease in yield was observed, no general method was previously available for synthesizing sevenmembered enaminones; in this regard, our new protocol has a unique advantage.

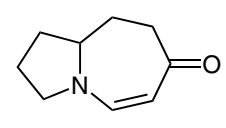

2.30

$60 \%(\mathrm{~A})$ $64 \%$ (B)

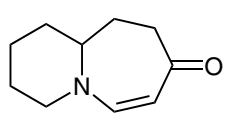

2.31

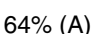
$63 \%(B)$

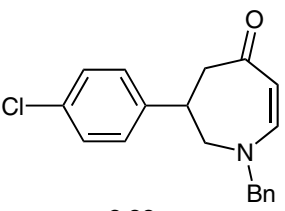

2.33

Isolated yields are specified.

A: (i) $4 \mathrm{~N} \mathrm{HCl} /$ dioxane (ii) $\mathrm{K}_{2} \mathrm{CO}_{3}, \mathrm{MeOH}$

B: (i) $\mathrm{Nal}$ (3 equiv), formic acid (ii) $\mathrm{K}_{2} \mathrm{CO}_{3}, \mathrm{MeOH}$

Scheme 6 Substrate scope for seven-membered enaminones ${ }^{16}$

\subsection{Mechanistic Studies}

With regard to the mechanism of cyclization, two pathways were proposed after the formation of the vinylogous

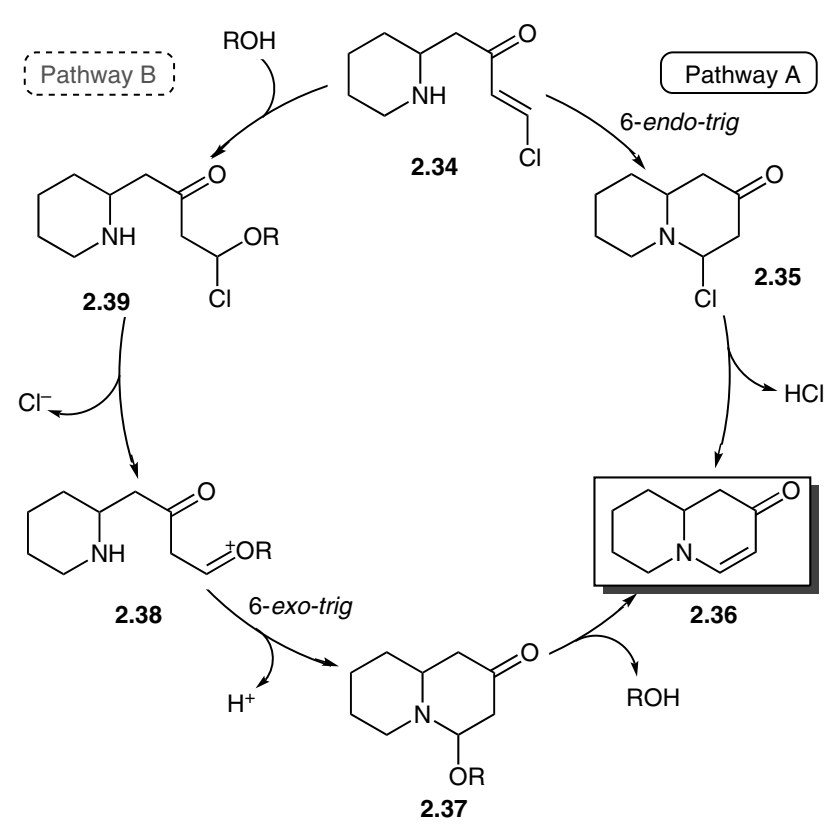

Figure 2 Two possible pathways for the cyclization acid chloride 2.34 (Figure 2) ${ }^{16}$ Initially, a simple 6-endotrig cyclization followed by liberation of hydrogen chloride was proposed (Pathway A). However, when the reaction was carried out in bulky alcoholic solvents $(s-\mathrm{BuOH}$ or $i-\mathrm{PrOH})$ or a non-nucleophilic solvents $\left(\mathrm{CH}_{2} \mathrm{Cl}_{2}\right.$ or THF), the reaction was significantly impaired. This observation was suggestive of an alternative mechanism (Pathway $\mathrm{B}$ ), in which the solvent $\mathrm{ROH}$ displaces chloride and leads to 6-exo-trig cyclization. ${ }^{16}$

To determine whether an alcohol was required for the cyclization, the reaction was conducted by using triethylamine as a base in three different solvents (Scheme 7). All three conditions provided the enaminone 2.41, suggesting that a nucleophilic solvent is not necessary.

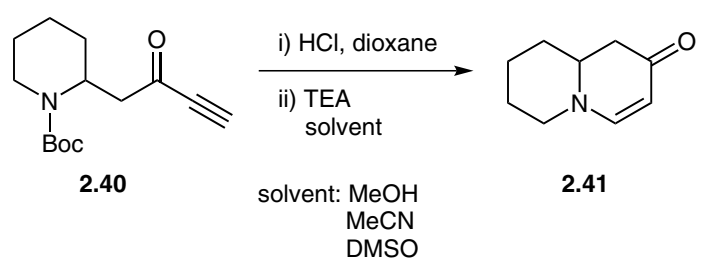

Scheme 7 Ynone cyclization using triethylamine as the base $\mathrm{e}^{16}$

To rule out the possibility that the cyclization is promoted by residual water, ynone $\mathbf{2 . 4 2}$, lacking an amine group, was prepared (Scheme 8). When ynone $\mathbf{2 . 4 2}$ was treated with hydrochloric acid, two intermediates $\mathbf{2 . 4 3}$ and $\mathbf{2 . 4 4}$ were formed in a ratio of 1:6. When these two species were subjected to basic conditions, the vinylogous acid chloride $\mathbf{2 . 4 3}$ was obtained as the sole product (Scheme 8). Upon addition of excess water, this compound remained intact. These results suggest that trace amounts of water do not promote the cyclization.

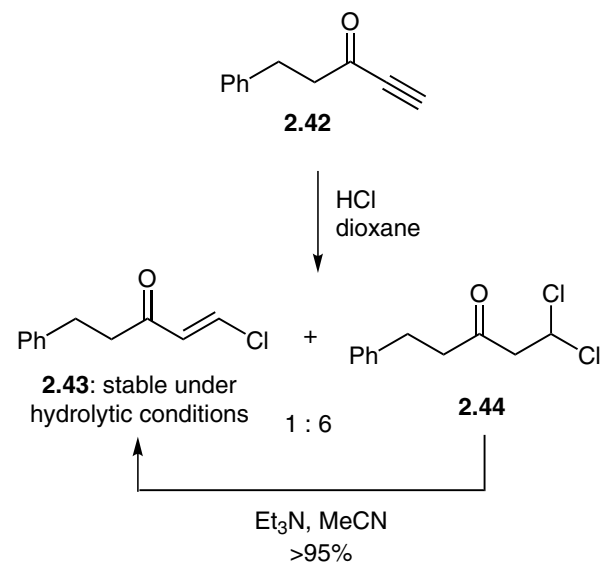

Scheme 8 Treatment of ynone $\mathbf{2 . 4 2}$ with hydrochloric acid

In a further exploration of the reaction mechanism, the two intermediates $\mathbf{2 . 4 3}$ and $\mathbf{2 . 4 4}$ were treated with potassium carbonate in methanol (Scheme 9). After two hours, only a $33 \%$ conversion was detected, suggesting that the addition of methanol to the vinylogous acid chloride is much slower than the cyclization. It is therefore reason- 
able to assume that the cyclization takes a 6-endo-trig mode (Pathway A). We postulated that the reason for failure to achieve cyclization in nonprotic solvents is insufficient solubility of potassium carbonate, whereas this base readily dissolves in methanol.<smiles>O=C(/C=C/Cl)CCc1ccccc1</smiles><smiles>CO/C=C/C(=O)CCc1ccccc1</smiles>

Scheme 9 Treatment of intermediates $\mathbf{2 . 4 3}$ and $\mathbf{2 . 4 4}$ with potassium carbonate in methanol

\subsection{Application to Quinolone Synthesis}

The ynone cyclization strategy was then used for the synthesis of a quinolone library. The synthesis of the ynones started from the anthranilic acids $\mathbf{2 . 4 6}$, which were protected with a tert-butoxycarbonyl group and converted into Weinreb amides $\mathbf{2 . 4 7}$ in one flask (Scheme 10). ${ }^{17}$ These amides were reacted with organomagnesium or organolithium reagents to give the desired ynones $\mathbf{2 . 4 8}$.
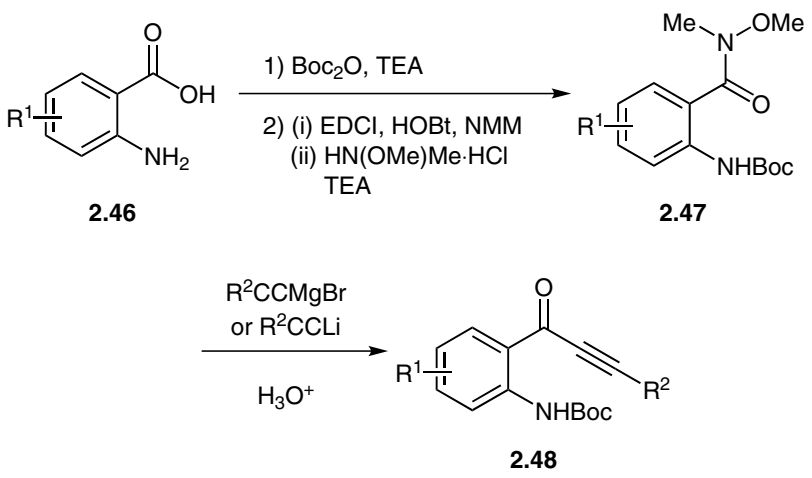

Scheme 10 Ynone syntheses from anthranilic acids

Next, the cyclization was conducted by using a one-flask procedure (Scheme 11). First, the $N$-tert-butoxycarbonyl ynone was treated with hydrochloric acid to remove the protecting group, and secondly, the resulting crude mixture was subjected to basic conditions by using potassium carbonate in methanol. Interestingly, this cyclization was slow enough to permit the observation of the Michael-adduct intermediate $\mathbf{2 . 4 9}$, formed by addition of methanol to the vinylogous acid chloride. In this case, therefore, a plausible mechanism involves a 6-endo-dig mode with methanol as the catalytic nucleophile. Because of the stability of intermediate $\mathbf{2 . 4 9}$ and the weaker nucleophilicity of the amino group, the cyclization requires heating at $50{ }^{\circ} \mathrm{C}$ for four days.
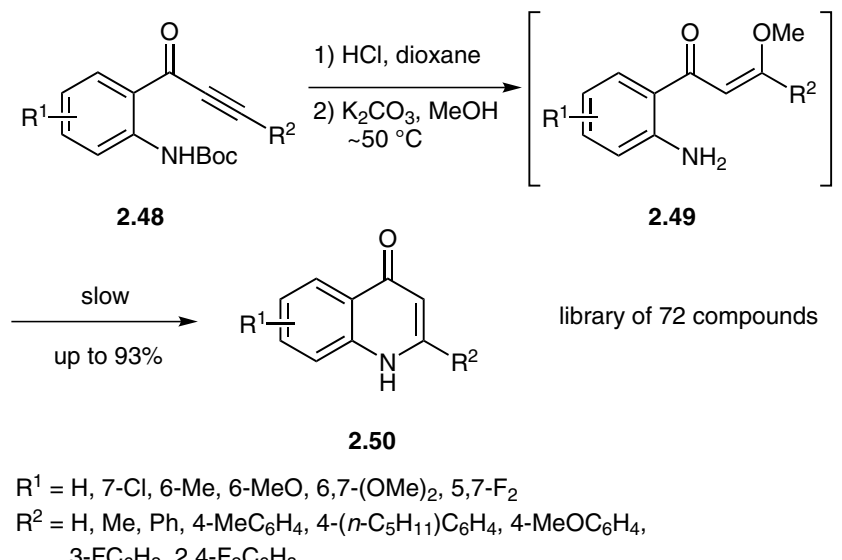
$3-\mathrm{FC}_{6} \mathrm{H}_{3}, 2,4-\mathrm{F}_{2} \mathrm{C}_{6} \mathrm{H}_{3}$

Scheme 11 Synthesis of quinolones from ynones

\subsection{N-Butoxycarbonyl $\beta$-Lactam Approach}

Having established a protocol for cyclizing ynones to enaminones, we turned our the focus on the synthesis of functionalized ynones. Specifically, it was envisioned that the ynone could be derived by nucleophilic ring opening of a $\beta$-lactam (Scheme 12). ${ }^{18}$ This synthesis started with the reaction of acid chloride $\mathbf{2 . 5 1}$ and imine $\mathbf{2 . 5 2}$ under Staudinger reaction conditions to give the $N$ - $p$-methoxyphenyl (PMP) protected $\beta$-lactam 2.53 with cis-configuration. The acetate group was cleaved, the resulting hydroxy group was protected with a silyl group, and the PMP $N$-protecting group was removed. The nitrogen was reprotected with a tert-butoxycarbonyl group to give the $\beta$-lactam 2.55, which was treated with an ethynyl Grignard reagent to afford the ynone $\mathbf{2 . 5 6}$.
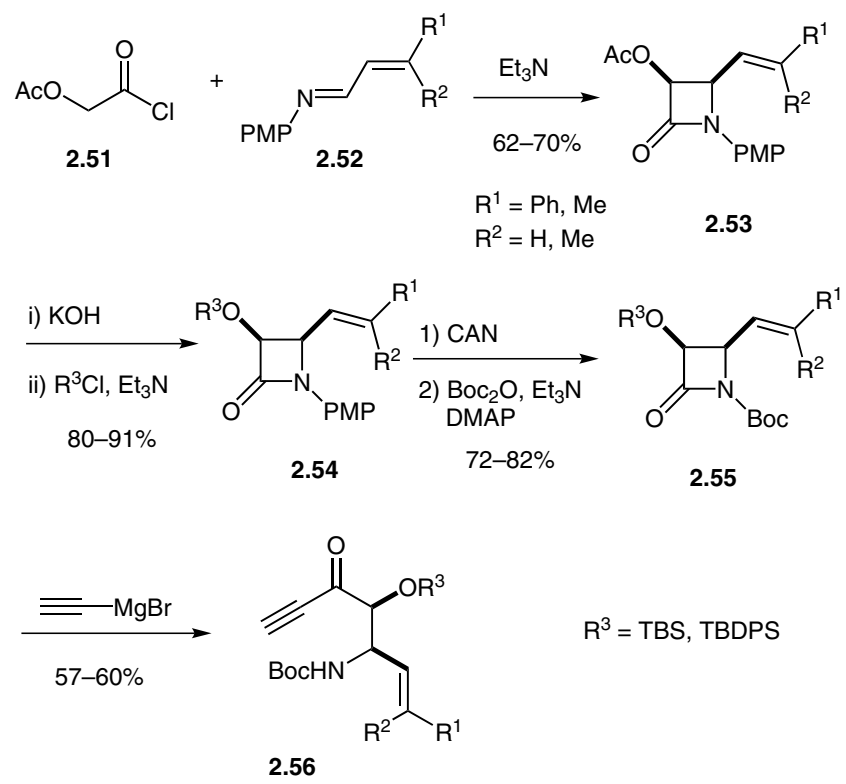

Scheme 12 Synthesis of functionalized ynones via a $\beta$-lactam 
Next, the ynones $\mathbf{2 . 5 6}$ were subjected to the one-flask procedure to provide the desired enaminones 2.57 in good yield (Scheme 13).<smiles>C#CC(=O)C(O)C(C=C)NC#N</smiles><smiles>O[Mg]O[Mg]</smiles>

2.56

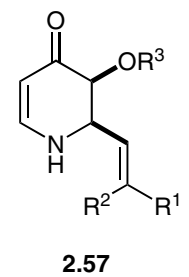

2.57

Scheme 13 Cyclization of ynones to enaminones

The nitrogen atom of the vinyl enaminones 2.57 was then functionalized with various terminal alkenes (Scheme 14). The resulting enaminones $\mathbf{2 . 5 8}$ were subjected to ring-closing metathesis conditions using the Grubbs II catalyst to give a variety of five-, six-, and seven-membered bicyclic enaminones 2.59. It is of interest that an $N$ acylated 2-phenyl analogue of $\mathbf{2 . 5 7}$ has recently been identified as an androgen receptor modulator. ${ }^{19}$

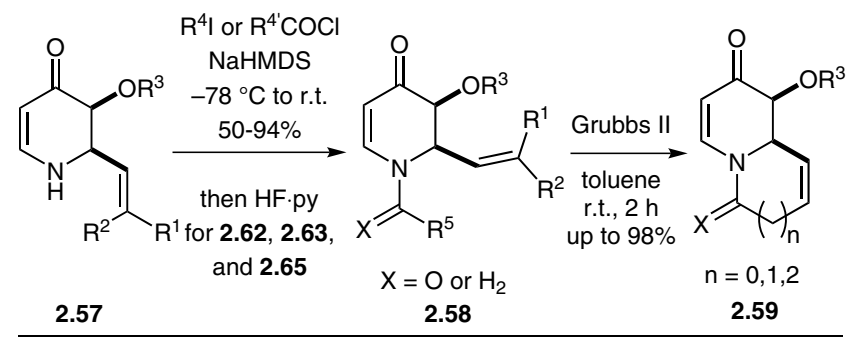<smiles>O=C1C=CN2CC=CC2C1O</smiles>

$2.60(98 \%)$

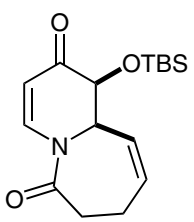

$2.64(74 \%)$<smiles>O=C1C=CN2CC=CC2C1O[SbH2]</smiles>

$2.61(89 \%)$<smiles>O=C1C=CN2C(=O)CCC=CC2C1O</smiles>

$2.65(98 \%)$

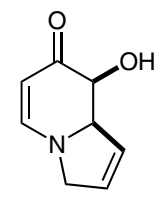

$2.62(87 \%)$

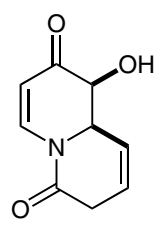

$2.63(50 \%)$

Scheme 14 Derivatization of enaminones to form bicyclic nitrogenous compounds

\subsection{Synthesis of 3,4-Dihydro-1,2-oxazepin- $5(2 H)$-ones and Their Conversion into Enam- inones}

One of the shortcomings of our chiral-pool approach is the limited array of possible substituents at the $\mathrm{C} 2$ position, simply due to the limited number of natural amino acids. To resolve this issue, we devised the retrosynthetic plan shown in Scheme 15. ${ }^{20}$<smiles>O=C1C=C([TlH])NCC1</smiles><smiles>C#CC(O)CC(Br)N(OC(=O)CC(=O)CC(C)N(OCc1ccccc1)C(=O)c1ccccc1)OC(=O)c1ccccc1</smiles><smiles>C=CC(=O)N(O)CC=O</smiles>

2.70

Scheme 15 Retrosynthetic plan to obtain enantiomerically-enriched enaminones

Although this approach is similar to our previous enaminone synthesis, the use of a protected hydroxylamine enabled us to synthesize aldehyde $\mathbf{2 . 7 0}$ with high enantioselectivity by employing MacMillan's organocatalytic method. ${ }^{21}$ We hypothesized that enaminone $\mathbf{2 . 6 6}$ might be readily synthesized from aldehyde $\mathbf{2 . 7 0}$ by means of our previous strategy and that the hydroxy group of $\mathbf{2 . 6 7}$ might be cleaved in a reductive fashion to provide enaminone 2.66.

With the aid of an imidazolidinone catalyst, protected hydroxylamine 2.71 underwent Michael addition to aldehyde $\mathbf{2 . 7 2}$ to give amino aldehyde $\mathbf{2 . 7 0}$ with excellent enantioselectivity (Scheme 16). The amino aldehyde $\mathbf{2 . 7 0}$ was then treated with a Grignard reagent, and the resulting propargyl alcohol 2.69 was oxidized with manganese dioxide to give the corresponding ynone. However, the desired product was not obtained under cyclization conditions. On the assumption that the tert-butyl(dimethyl)silyl group might attenuate the nucleophilicity of the amine group in the cyclization, we attempted a deprotection of the silyl group from the ynone. Interestingly, the resulting free hydroxy group underwent 7-endo-dig cyclization to afford the seven-membered product $\mathbf{2 . 7 4}$.

Although scaffold 2.74 had not previously been reported, we sought conditions to convert it into the enaminone 2.66. We found that the weak $\mathrm{N}-\mathrm{O}$ bond could be cleaved reductively with samarium(II) iodide, and upon deprotection of the tert-butoxycarbonyl group, an intermediate with the tentative diketone structure $\mathbf{2 . 7 5}$ underwent cyclization to provide enantiomerically enriched enaminone 2.66 (Scheme 17). 


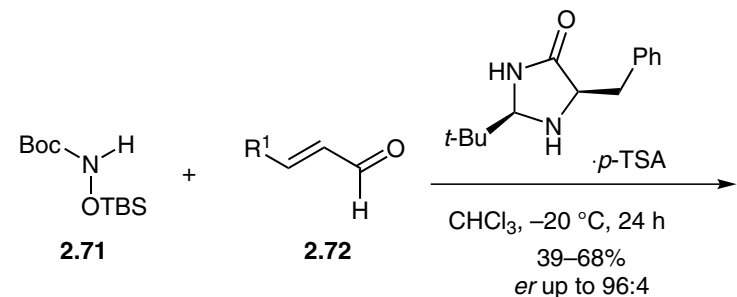

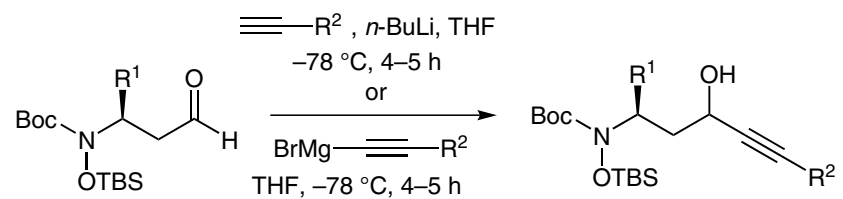

$270 \quad 21-3 \%$

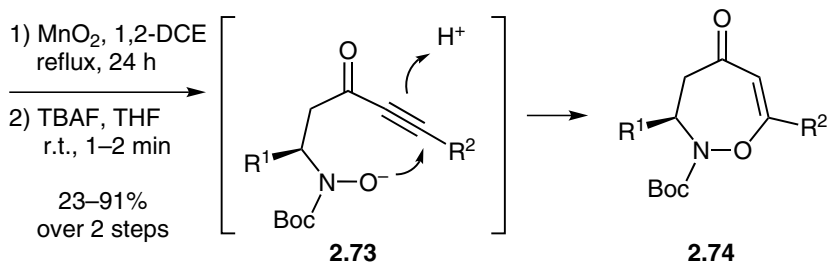

Scheme 16 Synthesis of an ynone and its cyclization<smiles>[R]C1=CC(=O)CC([Tl])N(C(=O)OC(C)(C)C)O1</smiles>

2.74

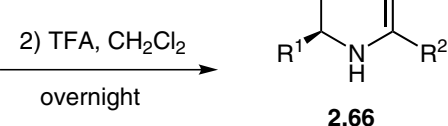

$\mathrm{R}^{1}=n-\mathrm{Pr}, \mathrm{R}^{2}=\mathrm{Ph}(\mathbf{2} .76) 64 \%$

$\mathrm{R}^{1}=n-\mathrm{Pr}, \mathrm{R}^{2}=4-\mathrm{CF}_{3} \mathrm{C}_{6} \mathrm{H}_{4}(\mathbf{2 . 7 7}) 83 \%$

$\mathrm{R}^{1}=n-\mathrm{Pr}, \mathrm{R}^{2}=$ thiophen-3-yl (2.78) $26 \%$

$\mathrm{R}^{1}=n-\operatorname{Pr}, \mathrm{R}^{2}=\mathrm{Me}(\mathbf{2 . 7 9}) 55 \%$

$\mathrm{R}^{1}=n-\mathrm{Pr}, \mathrm{R}^{2}=t-\mathrm{Bu}(\mathbf{2 . 8 0}) 70 \%$

$\mathrm{R}^{1}=\mathrm{CH}_{2} \mathrm{OBn}, \mathrm{R}^{2}=4-\mathrm{MeOC}_{6} \mathrm{H}_{4}$ (2.81) $46 \%$

Scheme 17 One-flask reductive cleavage of 3,4-dihydro-1,2-oxazepin-5(2H)-one $\mathbf{2 . 7 4}$ to obtain enaminone $\mathbf{2 . 6 6}$

\section{$3 \quad$ Ketene Cyclization}

As discussed above, our approach to synthesizing enaminones has a unique advantage in its use of amino acids. In some instances, however, partial racemization of the product occurred during the cyclization. Also, not all $\beta$ amino acids are readily available. To address these issues, we sought a different approach.

\subsection{Chiral-Pool Approach}

In the ynone cyclization, a retrosynthetic disconnection was made at $\mathrm{C}-\mathrm{N}$ bond of the enaminone (Scheme 18, bond a). As an alternative approach, a disconnection might be made at the $\alpha-\mathrm{C}-\mathrm{C}$ bond of the enaminone (bond b). We hypothesized that for a pendent enamine, a ketene should be an excellent electrophile that might be generated by Wolff rearrangement of the corresponding diazo ketone 3.3. ${ }^{22}$<smiles>[R]C#CC(=O)CC([R])N([R])C([R])=C[R]</smiles>

Scheme 18 Retrosynthetic analyses

The conversion of $\alpha$-amino acids 3.4 into a diazo ketones (Scheme 18) has a strong precedent in the Arndt-Eistert homologation. ${ }^{23}$ We began our efforts with the synthesis

Table 4 Optimization of the Reaction Conditions
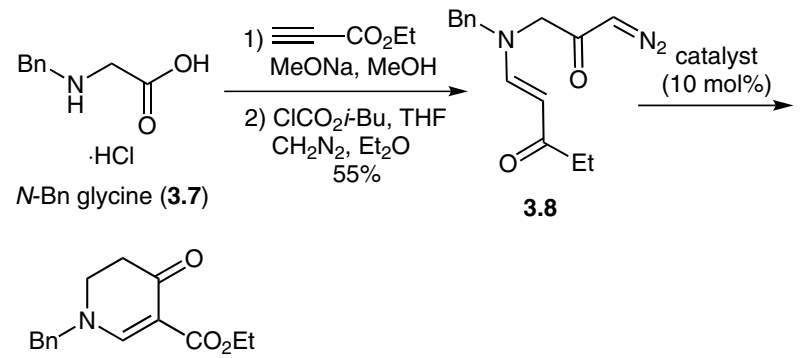

3.9

\begin{tabular}{lll}
\hline Run $^{\mathrm{a}}$ & Catalyst & Yield $^{\mathrm{a}}$ (\%) \\
\hline 1 & $\mathrm{Ag}_{2} \mathrm{O}$ & 90 \\
2 & $\mathrm{AgO}_{2} \mathrm{CCF}_{3}$ & 82 \\
3 & $\mathrm{AgOAc}^{\mathrm{b}}$ & 97 \\
4 & $\mathbf{A g O B z}$ & $\mathbf{9 9}$ \\
\hline${ }^{\mathrm{a}}$ Isolated yield. & &
\end{tabular}


of diazo ketone 3.8 (Table 4). First, $N$-benzylglycine hydrochloride (3.7) was treated with ethyl propiolate under basic conditions, to give a vinylogous carbamate. In the same flask, after evaporation of the solvent, the acid was subsequently converted into the diazo ketone 3.8. This process requires only a single purification by column chromatography. Having obtained the diazo ketone 3.8, we tested various silver salts that are frequently used in Arndt-Eistert homologations; several of these silver salts gave the desired product 3.9 in excellent yield.

On the basis of this study, we selected silver benzoate in dichloromethane as our standard conditions, and we subjected a variety of alkyne and amino acids to these optimized conditions to give the desired diazo ketones 3.123.18 (Scheme 19).

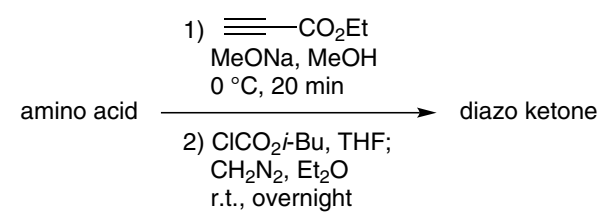<smiles>[R]C(=O)/C=C/N(CC(=O)C=N)Cc1ccccc1</smiles>

$\begin{aligned} \mathrm{R} & =\mathrm{OEt}(\mathbf{3 . 8 )} 55 \% \\ & =\mathrm{Ph}(\mathbf{3 . 1 0}) 46 \%\end{aligned}$

$=\mathrm{Me}(\mathbf{3 . 1 1}) 33 \%$<smiles>CCOC(=O)/C=C/N(C)C(CC(C)C)C(=O)C=N</smiles><smiles>CCOC(=O)/C=C/N1CCCC[C@H]1C(=O)C=N</smiles><smiles>CCOC(=O)/C=C/N1CCCC1C(=O)C=N</smiles>

3.14 $45 \%$ 3.15 $42 \%$ 3.16
$52 \%$<smiles>CCOC(=O)/C=C/N1C[C@H](C(C)(C)C)CC1C(=O)C=[W]</smiles><smiles>CCOC(=O)/C=C/N1Cc2ccccc2CC1C(=O)C=N</smiles>

3.17 $40 \%$

3.18 $48 \%$

Scheme 19 Synthesized diazo ketones

Each of the diazo ketones 3.12-3.18 was subjected to the conditions for the Wolff rearrangement to give various piperidine, indolizidine, and quinolizidine ring systems in high yields (Scheme 20).

Determination of the enantiomeric ratios of the products turned out to be challenging. Attempts to separate the enantiomers by using chiral HPLC or a chiral-shift reagent were unsuccessful. The enantiomeric purities were there-

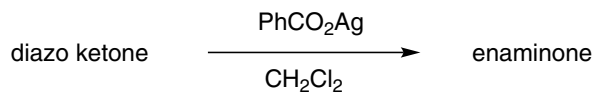

products and yields $^{\mathrm{a}}$<smiles>[R]C(=O)C1=CN(Cc2ccccc2)CCC1=O</smiles><smiles>CCOC(=O)C1=C(OCC)C(=O)CCN1Cc1ccccc1</smiles><smiles>CCOC(=O)C1=CN(C)C(C)CC1=O</smiles>

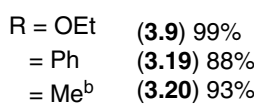
3.21 3.22<smiles>CCOC1=CN(C)C([13CH3])CC1=O</smiles><smiles>CCOC1=CN2CCCCC2CC1=O</smiles><smiles>CCOC(=O)C1=CN2CCCC2CC1=O</smiles>

3.23 $76 \%^{\mathrm{c}}$

3.24

3.25 $93 \%^{\mathrm{c}}$ $86 \%$ c,d<smiles>CCOC(=O)C1=CN2CC(OC(C)C)C[C@H]2CC1=O</smiles><smiles>CCOC(=O)C1=CN2Cc3ccccc3CC2CC1=O</smiles>

Scheme 20 Synthesized enaminones. Reaction conditions: diazo ketone, $\mathrm{PhCO}_{2} \mathrm{Ag}(10 \mathrm{~mol} \%), \mathrm{CH}_{2} \mathrm{Cl}_{2}(0.2 \mathrm{M})$, r.t., overnight. ${ }^{a}$ Isolated yields. ${ }^{\mathrm{b}} \mathrm{PhCO}_{2} \mathrm{Ag}(20 \mathrm{~mol} \%)$ was used. ${ }^{\mathrm{c}}$ The ee was determined by ${ }^{19} \mathrm{~F}$ NMR (Mosher ester derivatives); only one isomer was observed. ${ }^{\mathrm{d}} \mathrm{Ag}_{2} \mathrm{O}(10 \mathrm{~mol} \%)$ and DCE $(0.2 \mathrm{M})$ were used. ${ }^{\mathrm{e}} \mathrm{The} \mathrm{dr}$ was determined by ${ }^{1} \mathrm{H}$ NMR; one isomer was observed.

fore determined by ${ }^{19} \mathrm{~F}$ NMR spectroscopy of the corresponding Mosher esters. In the case of enaminone 3.26, only one isomer was observed by ${ }^{1} \mathrm{H}$ NMR spectroscopy.

\subsection{Three-Component Synthesis}

For the ketene cyclization, the appropriate diazo ketone precursors were prepared from amino acids by using diazomethane. Although the incorporation of chirality derived from an amino acid into the enaminone is attractive, the scale and scope of this method are limited by the need to use diazomethane, as well as by the limited solubility of amino acids in organic solvents. For example, $\mathrm{N}$-methylglycine could not be used as a substrate because of its insufficient solubility in methanol. Such shortcomings were addressed by an alternative retrosynthetic analysis. We speculated that the diazo ketones might be derived from three components: a primary amine 3.31, an alkyne 3.30, and 1-bromo-3-diazoacetone (3.32) (Scheme 21). ${ }^{24}$

By applying this disconnection, it should be possible to vary the substituents on the enaminone structure in a simple and convergent fashion, and to limit the use of diazomethane to the preparation of the common diazoacetone intermediate 3.32. To examine this hypothesis, we set our 
<smiles></smiles>

3.28<smiles>C=CC(=O)CBr</smiles>

Scheme 21 Retrosynthetic analysis

initial goal as the synthesis of known diazo ketone $\mathbf{3 . 8}$ (Scheme 22). The desired intermediate $\mathbf{3 . 8}$ was obtained by the Michael addition of 1-(benzylamine)-3-diazoacetone (3.33) in ethanol; the diazo compound $\mathbf{3 . 3 3}$ was, in turn, synthesized by treatment of 1-bromo-3-diazoacetone (3.32) with an excess of benzylamine.<smiles>C#CC(=O)OCC</smiles>

Scheme 22 Synthesis of diazo ketone $\mathbf{3 . 8 ^ { 2 4 }}$

Subsequently, several amino diazo ketones were prepared in a similar fashion from 1-bromo-3-diazoacetone (3.32) and alkyl amines 3.31 (Table 5). Several primary alkyl amines 3.31, including a chiral amine and tryptamine, were converted into the corresponding amino diazo ketones 3.29 in good yields.

The clean conversion of diazo ketone $\mathbf{3 . 3 3}$ into the azo keto ester 3.8 led us to attempt a Michael addition of the amino diazo ketone to an alkyne and a subsequent Wolff rearrangement in a single flask. We found that the use of two solvents (ethanol and dichloromethane) maximized the conversion and the yield. Under these conditions, a wide variety of enaminones were prepared in a single step from the corresponding amino diazo ketones (Scheme 23). In a few instances, silver oxide gave superior yields to silver benzoate.
Table 5 Synthesis of Diazo Ketones

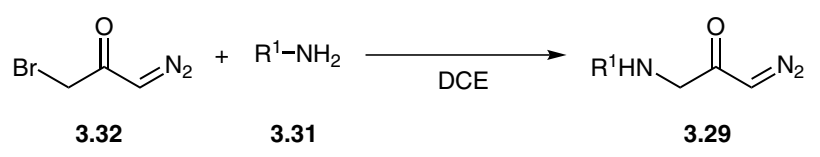

\begin{tabular}{|c|c|c|}
\hline Entry $^{\mathrm{a}}$ & Product & Yield (\%) \\
\hline 1 & $\mathrm{R}^{1}=\mathrm{Bn}(\mathbf{3 . 3 3})$ & 87 \\
\hline 2 & $\mathrm{R}^{1}=\mathrm{Et}(\mathbf{3 . 3 4})$ & 65 \\
\hline 3 & $\mathrm{R}^{1}=\operatorname{Pr}(\mathbf{3 . 3 5})$ & 63 \\
\hline 4 & $\mathrm{R}^{1}=\operatorname{All}(\mathbf{3 . 3 6})$ & 72 \\
\hline 5 & $\mathrm{R}^{1}=\mathrm{Bu}(\mathbf{3 . 3 7})$ & 80 \\
\hline 6 & $\mathrm{R}^{1}=\mathrm{CH}_{2} \mathrm{Cy}(\mathbf{3 . 3 8})$ & 81 \\
\hline 7 & $\mathrm{Me}$ & 93 \\
\hline
\end{tabular}

(3.39)

$8^{\mathrm{b}}$<smiles>N#CC(=O)CNCCc1c[nH]c2ccccc12</smiles>

(3.40)

a Reaction conditions: $\mathrm{BrCH}_{2} \mathrm{COCH}=\mathrm{N}_{2}$, amine (4 equiv), $\mathrm{DCE}(0.25$ $\mathrm{M}), 50^{\circ} \mathrm{C}, 3 \mathrm{~h}$.

${ }^{\mathrm{b}} \mathrm{A}$ soln of $\mathrm{BrCH}_{2} \mathrm{COCH}=\mathrm{N}_{2}(0.25 \mathrm{M})$ in methanolic $\mathrm{NaOMe}(0.5 \mathrm{M})$ was treated with tryptamine $\cdot \mathrm{HCl}$ (2 equiv) at $50{ }^{\circ} \mathrm{C}$ for $3 \mathrm{~h}$.

\section{$4 \quad$ C5 Functionalization}

\subsection{Suzuki Coupling of Iodoenaminones}

If we consider the embedded enamine functionality in enaminones, it is not surprising that the $\mathrm{C} 5$ position exhibits nucleophilicity. In fact, iodination occurs readily at the C5 position unless the substituent on the nitrogen is an electron-withdrawing group. Comins and Joseph ${ }^{10}$ and Kranke and Kunz ${ }^{11}$ have shown that this iodoenaminones undergo a variety of palladium-catalyzed reactions, such as Stille or Negishi cross-couplings, although the reaction conditions have not been optimized. ${ }^{10,11}$

We found that the iodoenaminones 4.2 underwent Suzuki coupling with arylboronic acids under microwave conditions in good to excellent yields (Scheme 24). ${ }^{25}$

\subsection{Suzuki-Type Direct Cross-Coupling}

Once a two-step protocol was available for functionalizing the C5 position, a more direct method was envisaged that would eliminate the need for preactivation of the enaminone. We surmised that, by taking advantage of the innate nucleophilic character of enaminone, a palladiumenaminone species might be derived from the nonactivat- 


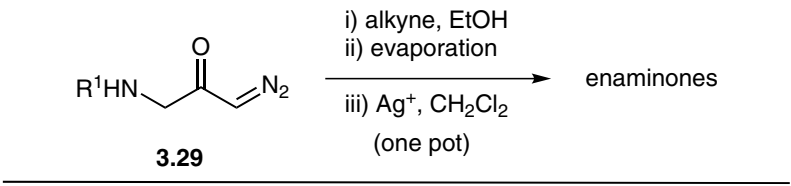<smiles>CCOC(=O)C1=CN([Tl])CCC1=O</smiles>

$\mathrm{R}^{1}=\mathrm{Et}(\mathbf{3 . 4 1}) 85 \%$ $n-\operatorname{Pr}(\mathbf{3 . 4 2}) 67 \%$ allyl (3.43) $76 \%$ $n$-Bu (3.44) $78 \%$ $\mathrm{CH}_{2} \mathrm{Cy}(3.45) 88 \%$ $\mathrm{Bn}(3.9) 82 \%$<smiles>[Y]N1C=C(C(C)=O)C(=O)CC1</smiles>

$\mathrm{R}^{1}=\mathrm{Et}(\mathbf{3 . 4 9 )} 94 \%$ $n-\operatorname{Pr}(\mathbf{3 . 5 0}) 84 \%$ allyl (3.51) $90 \%$ $n$-Bu (3.52) $81 \%$ $\mathrm{CH}_{2} \mathrm{Cy}(3.53) 92 \%$ Bn (3.20) $85 \%$<smiles>[R]C1=C([R])N([C@H](C)c2ccccc2)CCC1=O</smiles>

$\mathrm{R}^{2}=\mathrm{CO}_{2} \mathrm{Et}, \mathrm{R}^{3}=\mathrm{H}(3.59) 86 \%$ $\mathrm{R}^{2}=\mathrm{CO}_{2} \mathrm{Et}, \mathrm{R}^{3}=\mathrm{CO}_{2} \mathrm{Et}(\mathbf{3 . 6 0}) 67 \%$ $\mathrm{R}^{2}=\mathrm{C}(\mathrm{O}) \mathrm{Me}, \mathrm{R}^{3}=\mathrm{H}(\mathbf{3 . 6 1}) 75 \%$ $R^{2}=C(O) P h, R^{3}=H(3.62) 81 \%$<smiles>[R]C1=C(P)N(CCc2c[nH]c3ccccc23)CCC1=O</smiles>

$\mathrm{R}^{2}=\mathrm{CO}_{2} \mathrm{Et}, \mathrm{R}^{3}=\mathrm{H}(\mathbf{3 . 6 3}) 76 \%$ $\mathrm{R}^{2}=\mathrm{CO}_{2} \mathrm{Et}, \mathrm{R}^{3}=\mathrm{CO}_{2} \mathrm{Et}(\mathbf{3 . 6 4}) 73 \%$ $\mathrm{R}^{2}=\mathrm{C}(\mathrm{O}) \mathrm{Me}, \mathrm{R}^{3}=\mathrm{H}(\mathbf{3 . 6 5}) 61 \%$

Scheme 23 Synthesis of an enaminone library from three components. ${ }^{24}$ Reaction conditions: amino diazo ketone ( 1 equiv), alkyne (1.2 equiv), EtOH $(0.2 \mathrm{M})$, then evaporation, $\mathrm{AgOBz}$ or $\mathrm{Ag}_{2} \mathrm{O}(20$ mol\%), $\mathrm{CH}_{2} \mathrm{Cl}_{2}(0.2 \mathrm{M})$, darkness.

ed enaminone; this would be followed by $\mathrm{C}-\mathrm{C}$ bond formation with a suitable coupling partner to permit the twostep process to become a catalytic one-step method. A direct palladium(II)-catalyzed arylation of enaminone $\mathbf{4 . 1 3}$ was successfully achieved by using an aryl(trifluoro)borate as a coupling partner in a mixture of three solvents (Scheme 25) to give the aryl derivative 4.14. ${ }^{26}$ Acetic acid was used to promote palladation by increasing the electrophilicity of the palladium(II) center. Consequently, trifluoroborates, known to be robust equivalents of organoboronic acids, were chosen as coupling partners because other coupling partners, including boronic acids or organozinc reagents, are sensitive to acidic conditions. Slow addition of the trifluoroborate was necessary to avoid its dimerization.

The scope for the aryl(trifluoro)borate was then investigated under the optimized conditions (Scheme 26). As expected, electron-rich aryl(trifluoro)borates coupled

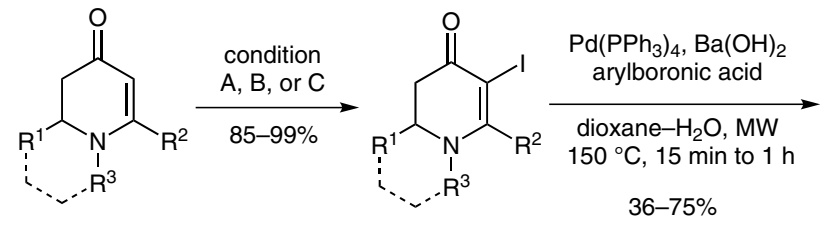

4.1

4.2<smiles>[R]C1=C(Br)C(=O)CC2CCCN12</smiles>

conditions

A: $\mathrm{I}_{2}$, py, $\mathrm{CCl}_{4}, 0^{\circ} \mathrm{C}$ to r.t., $5 \mathrm{~h}$

B: $\mathrm{I}_{2}, \mathrm{Et}_{3} \mathrm{~N}, \mathrm{CH}_{2} \mathrm{Cl}_{2}$, r.t., $5 \mathrm{~min}$

C: $\mathrm{I}_{2}$, DMAP, $\mathrm{CH}_{2} \mathrm{Cl}_{2}$, r.t., overnight<smiles>CCCN1CCCCC1CC(=O)C1=C(P)CCCC1</smiles>

$R^{7}=\mathrm{H}(\mathbf{4 . 1 1}) 72 \%$

$R^{7}=\operatorname{Ph}(4.12) 60 \%$

Scheme 24 Examples of Suzuki coupling reactions of iodoenaminones

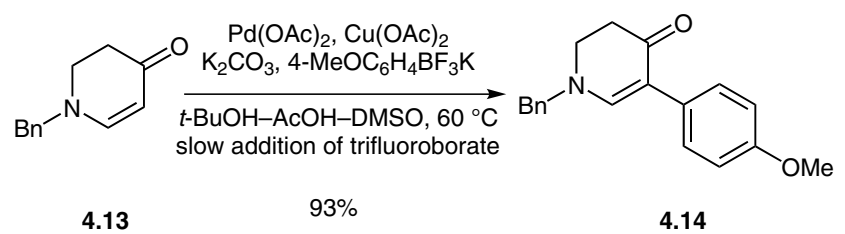

Scheme 25 Direct arylation of an enaminone

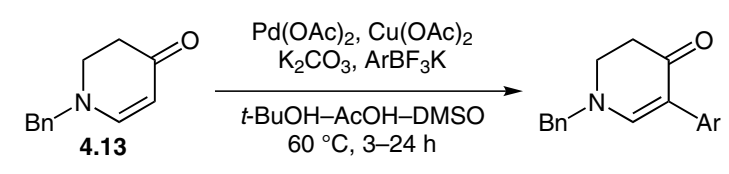

$\begin{aligned} \mathrm{Ar} & =\mathrm{Ph}(\mathbf{4 . 1 5}) 72 \% & & =4-\mathrm{BrC}_{6} \mathrm{H}_{4}(\mathbf{4 . 2 1}) 73 \% \\ & =4-\mathrm{MeC}_{6} \mathrm{H}_{4}(\mathbf{4 . 1 6}) 86 \% & & =4-\mathrm{ClC}_{6} \mathrm{H}_{4}(\mathbf{4 . 2 2}) 71 \% \\ & =2-\mathrm{MeC}_{6} \mathrm{H}_{4}(\mathbf{4 . 1 7}) 40 \% & & =2-\text { naphthyl }_{4}(\mathbf{4 . 2 3}) 96 \% \\ & =2-\mathrm{MeOC}_{6} \mathrm{H}_{4}(\mathbf{4 . 1 8}) 27 \% & & =3,4,5-\left(\mathrm{MeO}_{3} \mathrm{C}_{6} \mathrm{H}_{2}(\mathbf{4 . 2 4}) 83 \%\right. \\ & =4-\mathrm{F}_{3} \mathrm{CC}_{6} \mathrm{H}_{4}(\mathbf{4 . 1 9}) 44 \% & & =3-\mathrm{HOC}_{6} \mathrm{H}_{4}(\mathbf{4 . 2 5}) 97 \% \\ & =4-\mathrm{AcC}_{6} \mathrm{H}_{4}(\mathbf{4 . 2 0}) 42 \% & & =4-\mathrm{CbzNHC}_{6} \mathrm{H}_{4}(\mathbf{4 . 2 6}) 80 \%\end{aligned}$

Scheme 26 Scope of trifluoroborates

efficiently. Electron-deficient or sterically hindered aryl(trifluoro)borates gave moderate yields in extended periods of time. Notably, halo groups on the aryl moieties remained intact, potentially serving as positions for further derivatization.

Next, we examined the scope of enaminones for the reaction (Scheme 27). We found that monocyclic or bicyclic 

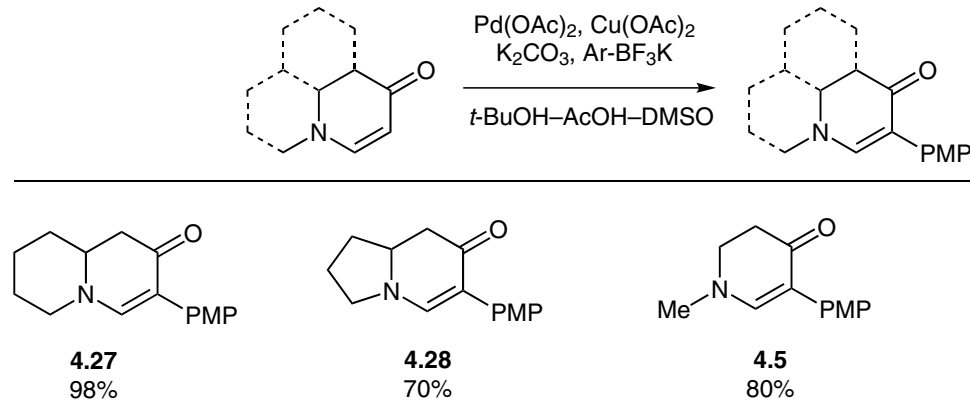<smiles>CN1C=C(P)C(=O)CC1</smiles><smiles>N#CC1=CN(Cc2ccccc2)C(c2ccccc2)CC1=O</smiles><smiles>CN1C=C([NH3+])C(=O)C2CCCCC21</smiles><smiles>CN1C=C([N+]#N)C(=O)C2CCCC[C@H]21</smiles><smiles>CC(C)(C)OC(=O)N1C=C(P)C(=O)CC1</smiles>

4.30

Scheme 27 Scope of enaminones

enaminones were viable substrates. The $N$-butoxycarbonyl-protected enaminone 4.32, however, was inactive in the cross coupling.

It is possible that the coupling is initiated by nucleophilic attack of the enaminone $\mathbf{4 . 3 3}$ on palladium to give the palladium-enaminone intermediate 4.34 (Scheme 28). ${ }^{26}$ This palladium species might then undergo transmetalation with the aryltrifluoroborate followed by reductive elimination to give the arylated enaminone 4.36. Alternatively, the catalytic cycle might start with transmetalation between the palladium species and the aryl(trifluoro)borate species. The palladium-aryl intermediate would then serve as an electrophile for the enaminone 4.33. The formation of a biaryl byproduct was observed, which supports the formation of the palladium-aryl intermediate.

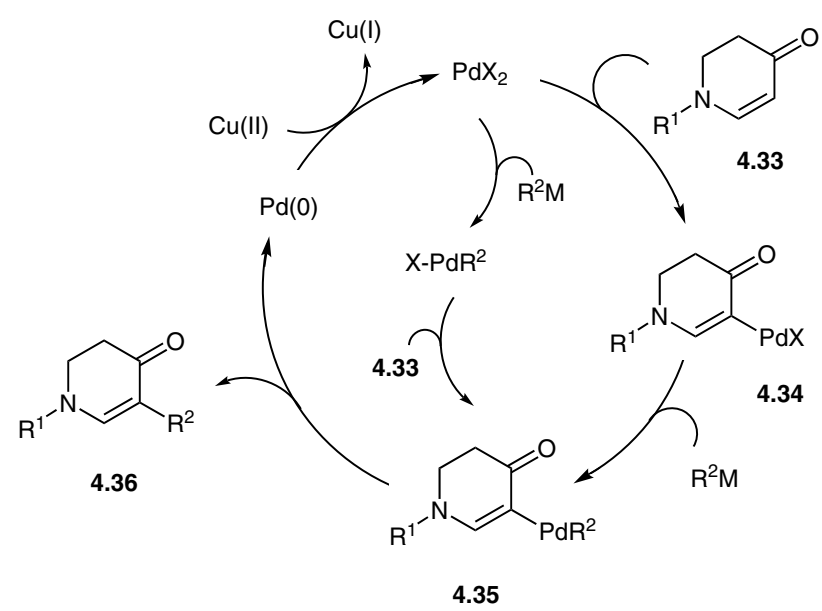

Scheme 28 Proposed catalytic cycle for direct arylation of enaminones

\subsection{Suzuki-Type Direct Cross-Coupling with Arylboronic Acids}

Although the direct Suzuki-type cross-coupling of the enaminone with aryltrifluoroborates was successful, it was necessary to explore other partners for the coupling reaction because of the limited number of aryl(trifluoro)borates that are commercially available. Boronic acids were selected as the most promising alternative, and conditions for their cross-coupling reactions were investigated. Smooth coupling was observed under optimized conditions when copper(II) acetate and copper(II) chloride were used with various boronic acids in $N, N$-dimethylformamide (Scheme 29). ${ }^{27}$

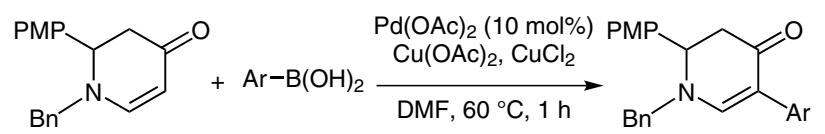
4.37

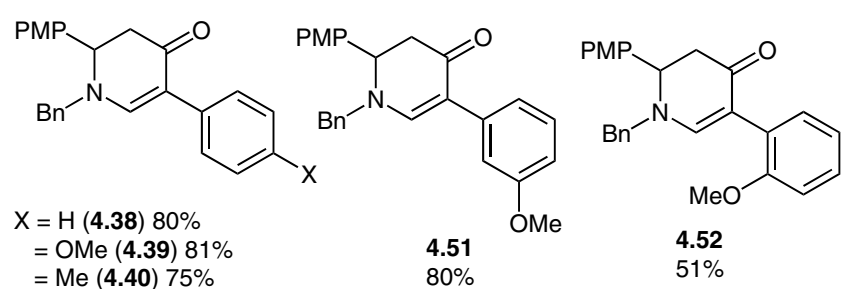

$=\mathrm{OH}(4.41) 62 \%$

$=\mathrm{F}(\mathbf{4 . 4 2}) 85 \%$

$=\mathrm{Cl}(\mathbf{4 . 4 3}) 78 \%$

$=\mathrm{Br}(\mathbf{4 . 4 4 )} 86 \%$

$=\mathrm{CF}_{3}(\mathbf{4 . 4 5}) 80 \%$

$=\mathrm{CONH}_{2}$ (4.46) $74 \%$

$=$ COMe (4.47) $82 \%$

$=\mathrm{NO}_{2}(\mathbf{4 . 4 8}) 90 \%$

$=\mathrm{CN}(4.49) 78 \%$

$=\mathrm{CHO}(4.50) 83 \%$<smiles>CC(C)CC1CC(=O)C(c2ccc3ccccc3c2)=CN1Cc1ccccc1</smiles><smiles>CCCCN1C=C(c2ccsc2)C(=O)CC1PN</smiles>
$24 \%$

Scheme 29 Scope of the boronic acids

This protocol was applied to various enaminones (Scheme 30 ), confirming the wide scope and broad functionalgroup compatibility of this approach.

We found that, in most cases, the electronic nature of boronic acids did not affect the coupling yield, which is a considerable advantage over the previous method with ar- 


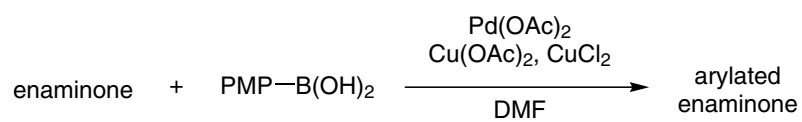<smiles>[Y6]C1=CN([R])CCC1=O</smiles>

$\mathrm{R}=\mathrm{Bn}(\mathbf{4 . 1 4}) 70 \%$ $=\mathrm{Ph}(\mathbf{4 . 5 5}) 60 \%$

$=\operatorname{Me}(\mathbf{4 . 5}) 65 \%$<smiles>[Y10]C1=CN(C)C2CCCCC2C1=O</smiles>
4.30
$76 \%$<smiles>CN1C=C(P)C(=O)[C@@H]2CCCC[C@H]21</smiles><smiles>O=C1CC2CCCCN2C=C1P</smiles>

4.27

$82 \%$<smiles>O=C1CC2CCCN2C=C1P</smiles>

4.28

$56 \%$<smiles>CC1=C([N+]#N)C(=O)CCN1Cc1ccccc1</smiles>

4.56

$61 \%$
Scheme 30 Scope of the enaminone substrates

yltrifluoroborates. On the basis of this observation, we proposed that the mechanism of the reaction is slightly different from that of the trifluoroborate reaction. We hypothesized that the mixture of the key components copper(II) acetate and copper(II) chloride not only reoxidizes palladium, but also facilitates transmetalation to deliver the aryl group onto the palladium-enaminone species through a putative aryl-copper intermediate.

\subsection{Hiyama-Type Direct Cross-Coupling}

We turned our attention to the Hiyama coupling of organosilicon reagents as an alternative cross-coupling protocol to the boron-based approach. On the basis of our results for the Suzuki coupling, we screened a wide variety of palladium catalysts, oxidants, and silicon activators. The reaction was successful when palladium(II) acetate and copper(II) fluoride were used in a cosolvent system (Scheme 31). ${ }^{28}$ In this reaction, copper(II) fluoride acts both as an oxidant for palladium and as an activator for the aryl(triethoxy)silane. When we examined the substrate scope for this reaction, we found that various enaminones and aryl triethoxysilanes are viable substrates for the coupling. Note that the tert-butyl(dimethyl)silyl group remained intact under the reaction conditions, but would have been removed under typical Hiyama conditions (tetrabutylammonium fluoride). As observed in the Suzuki coupling, halo substituents on aryl groups and enaminones also remained intact.

\subsection{Direct Coupling with Aryl Iodides}

Because they are available commercially or can be readily synthesized, aryl iodides appeared to be the most practical coupling partners for the C5 functionalization of enaminones. However, the double bond of the enaminone might also serve as a Heck donor to afford C6 arylated enami-

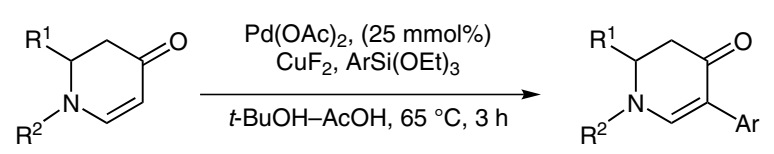<smiles>[X]c1ccc(C2=CN(Cc3ccccc3)C(c3ccccc3)CC2=O)cc1</smiles><smiles>O=C1CC(c2ccccc2)N(Cc2ccccc2)C=C1c1cccc2ccccc12</smiles><smiles>O=C1CCN(Cc2ccccc2)C=C1c1ccccc1</smiles>

$$
\begin{aligned}
\mathrm{X} & =\mathrm{Me}(\mathbf{4 . 5 7}) \mathbf{8 5} \% \\
& =\mathrm{CF}_{3}(\mathbf{4 . 5 8 )} 73 \% \\
& =\mathrm{OMe}(\mathbf{4 . 2 9 )} 50 \% \\
& =\mathrm{Cl}(\mathbf{4 . 5 9 )} 65 \% \\
& =\mathrm{Br}(\mathbf{4 . 6 0 )} 61 \%
\end{aligned}
$$<smiles>O=C1CC2CCCCN2C=C1c1ccccc1</smiles><smiles>CC(C)(C)OCCCN1C=C(c2ccccc2)C(=O)CC1c1ccccc1</smiles>

$$
\begin{aligned}
& 4.62 \\
& 72 \%
\end{aligned}
$$

4.63<smiles>CC1CC(=O)C(c2ccccc2)=CN1Cc1ccccc1Br</smiles><smiles>O=C1CC(c2ccccc2)N(C(=O)Oc2ccccc2)C=C1c1ccccc1</smiles>

Scheme 31 Scope of the Hiyama coupling

nones. This problem of regioselectivity was overcome by careful optimization of the reaction conditions using silver salts (Scheme 32) ${ }^{29}$ The silver salts and dimethyl sulfoxide presumably contribute to the production of an electrophilic arylpalladium(1+) species by abstracting iodide and stabilizing the cation, leading to the suppression of carbopalladation (the Heck pathway). The scope of this reaction was explored with respect to both the aryl iodide and the enaminone.

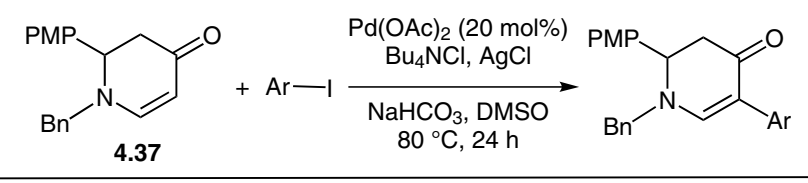<smiles>[X]c1ccc(C2=CN(Cc3ccccc3)C([Y16])CC2=O)cc1</smiles><smiles>[X]c1cccc(C2=CN(Cc3ccccc3)C(P)CC2=O)c1</smiles>

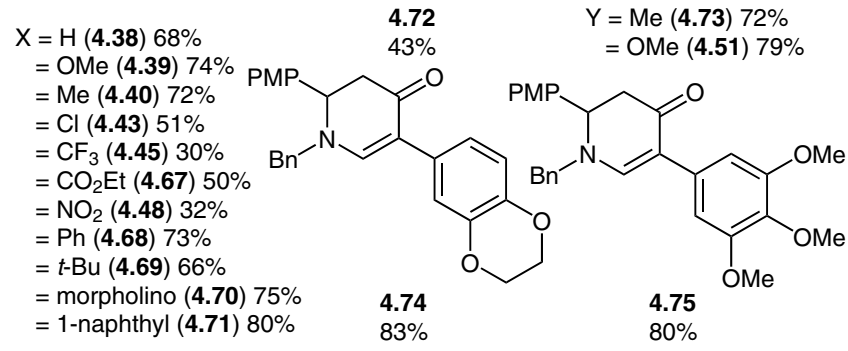

Scheme 32 Scope of the coupling with aryl iodides 


\subsection{Alkenylation by the Fujiwara-Moritani Reaction}

Encouraged by our success in direct arylation of the enaminones, we investigated their direct alkenylation. ${ }^{30}$ This was unsuccessful under Suzuki reaction conditions because of the rapid homocoupling of alkenyl(trifluoro)borates. To address this problem, we considered the Fujiwara-Moritani reaction (Scheme 33). ${ }^{31-33}$ The Fujiwara-Moritani reaction starts with the formation of an aryl-palladium complex 4.76 that undergoes by carbopalladation by an olefin 4.78 and subsequent reductive elimination to give the alkene 4.79. By assuming that a palladium-enaminone intermediate exists in our catalytic cycle and has an aryl-palladium-like property, we surmised that alkenylation might be possible by using a terminal alkene as a coupling partner. The reaction conditions were optimized by screening various palladium catalysts, oxidants, and additives.

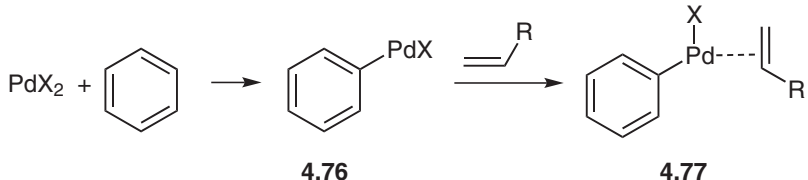<smiles>[R]C=Cc1ccccc1</smiles>
4.78 4.79

Scheme 33 The Fujiwara-Moritani reaction

By using an activated olefin as the coupling partner and potassium trifluoroacetate as an additive, we obtained the alkenylated enaminone product (Scheme 34). A wide variety of olefins with electron-withdrawing groups were found to be viable substrates in this reaction. However, acrylic acid and vinyl ethers failed to afford the desired products 4.89 and 4.90 , respectively.

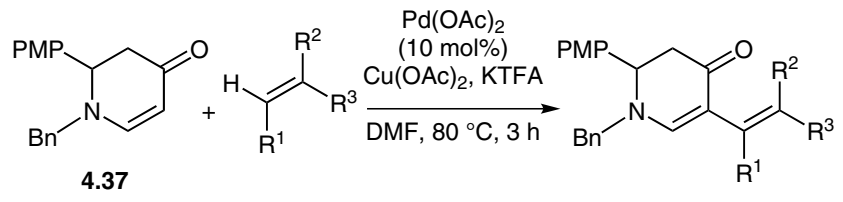<smiles>[X]C=CC1=CN(Cc2ccccc2)C([R16])CC1=O</smiles>

$\mathrm{X}=\mathrm{CO}_{2} t-\mathrm{Bu}(\mathbf{4 . 8 0}) 81 \%$ $=\mathrm{CO}_{2} \mathrm{Me}(\mathbf{4 . 8 1}) 82 \%$

$=\mathrm{CO}_{2} \mathrm{Bn}(4.83) 91 \%$

= COMe (4.84) $85 \%$

$=\mathrm{CONMe}_{2}$ (4.85) 95\%

$=\mathrm{P}(\mathrm{O})(\mathrm{OEt})_{2}(\mathbf{4 . 8 6}) 68 \%$

$=\mathrm{Ph}(\mathbf{4 . 8 7}) 66 \%$

$=\mathrm{SO}_{2} \mathrm{Me}$ (4.88) $56 \%$

$=\mathrm{CO}_{2} \mathrm{H}(4.89)<3 \%$

$=\mathrm{O} n-\mathrm{Bu}(\mathbf{4 . 9 0})<3 \%$

PMP<smiles>CC(=O)C=C(C)C1=CN(Cc2ccccc2)C(C(C)(C)C)CC1=O</smiles>

$42 \%$
$=\mathrm{CO}_{2} n-\mathrm{Bu}(\mathbf{4 . 8 2}) 87 \%$<smiles>[Y]C1COC(=O)C1=CC1=CN(Cc2ccccc2)C(C(C)C)CC1=O</smiles>

4.91

$83 \%(\alpha \beta / \beta \gamma=1: 2.5)$<smiles>CCCCC1CC(=O)C(C2C=CC=[Y]C2)=CN1Cc1ccccc1</smiles>

4.93

$49 \%(\alpha \beta / \beta \gamma=1: 1.1)$
Scheme 34 Scope of olefins in the alkenylation of enaminones

Next, we carried out this alkenylation by using various enaminones (Scheme 35), and we found that the protocol is applicable to mono- and bicyclic enaminones. Impor-

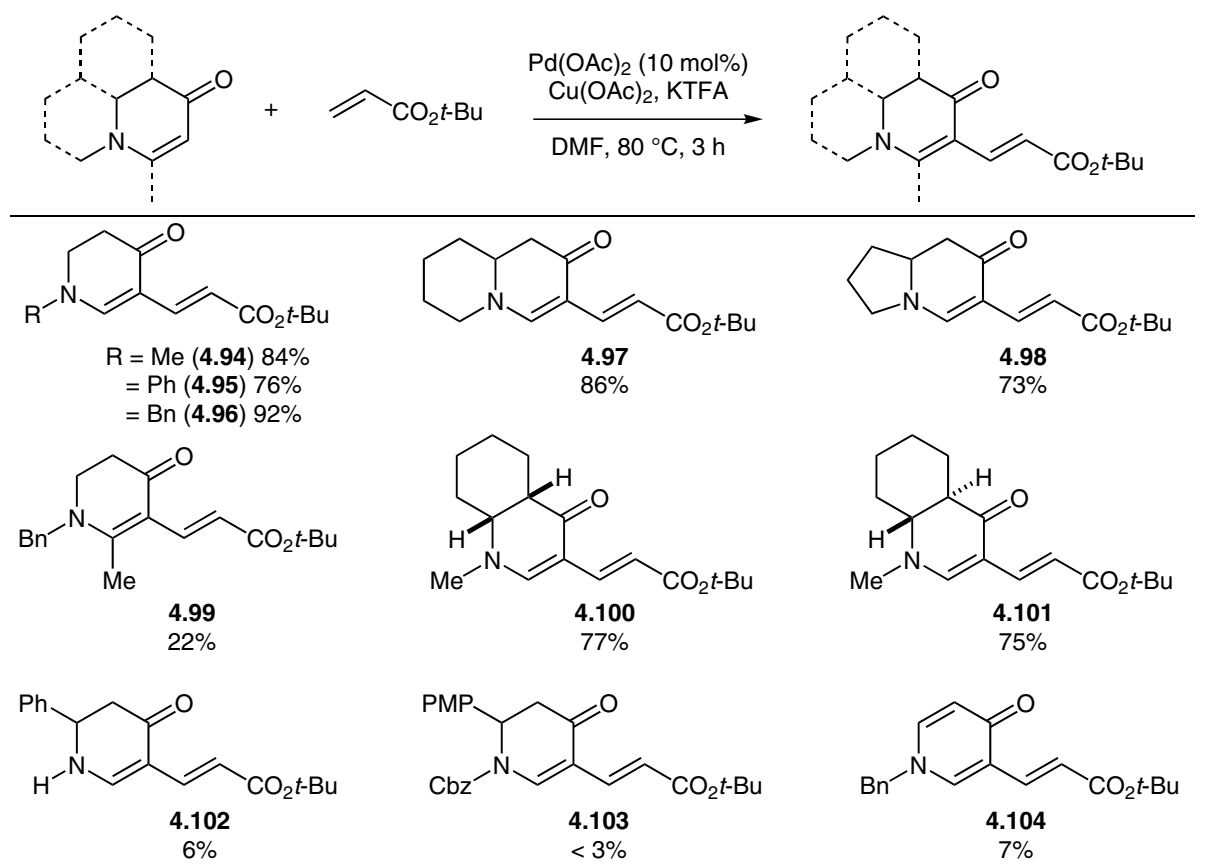

Scheme 35 Scope of enaminones in the alkenylation of enaminones 
tantly, stereochemical integrity was retained during the transformation, yielding enaminones 4.100 and 4.101 without epimerization. As previously observed in the Suzuki and Hiyama reactions, $N$-unsubstituted and $N$-benzyloxycarbonyl enaminones were not viable substrates (4.102 and 4.103). 1-Benzylpyridin-4(1H)-one was also a poor substrate for this coupling reaction (4.104).

During the course of this study, we conducted NMR experiments in an attempt to identify the palladium-enaminone intermediate, presumed to be the key intermediate species for the coupling reactions (Scheme 36). The enaminone 4.37 was treated with 0.5 or 1.0 equivalents of palladium(II) acetate in dimethyl sulfoxide for $20 \mathrm{~min}$ utes. The disappearance of the two doublet peaks at 7.62 and $4.79 \mathrm{ppm}$ and the appearance of a singlet peak at 7.72 ppm indicated that the enaminone was converted into the palladium-enaminone intermediate $\mathbf{4 . 1 0 5}$.

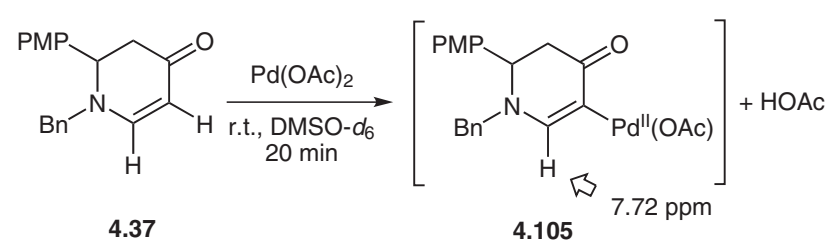

Scheme 36 NMR studies to detect the palladium-enaminone intermediate

This intermediate $\mathbf{4 . 1 0 5}$ was then subjected to alkenylation in dimethyl sulfoxide (Scheme 37). Upon heating the reaction to $140{ }^{\circ} \mathrm{C}$, the alkenylated product 4.80 was observed.

$$
\begin{aligned}
& \underset{\mathrm{DMSO}_{-d_{6}}}{\stackrel{\mathrm{Pd}(\mathrm{OAC})_{2}}{\longrightarrow}} \\
& \underset{\mathrm{CO}_{2} t-\mathrm{Bu}}{\stackrel{\mathrm{DMSO}-d_{6}}{140{ }^{\circ} \mathrm{C}, 0.5 \mathrm{~h}}} \\
& \text { } \\
& 4.80
\end{aligned}
$$

Scheme 37 Stoichiometric alkenylation for mechanistic investigation

\subsection{Alkenylation of Uracils}

We also applied the Fujiwara-Moritani protocol (see Section 4.6) to olefination of uracils at the $\mathrm{C} 5$ position. ${ }^{34} \mathrm{Al}-$ though $\mathrm{C} 5$ alkenylation had been reported previously in the context of biological investigations on uracil derivatives, preactivated uracils and metalated alkenes were used in most cases. ${ }^{35,36}$ With the aim of streamlining these inefficient processes, we developed a direct dehydrogenative coupling, based on results from our enaminone chemistry.
We found that 1,3-dimethyluracil (4.106) underwent coupling with tert-butyl acrylate in $N, N$-dimethylformamide in the presence of palladium(II) acetate as a catalyst to give the C5-alkenyl derivative $\mathbf{4 . 1 0 7}$ in $92 \%$ yield (Scheme 38). The key additives were silver(I) acetate, which acts as an effective palladium oxidant, and pivalic acid, which presumably lowers the energy of the transition state and facilitates palladation of the uracil. ${ }^{34} \mathrm{We}$ examined the scope of this reaction with various olefins (Scheme 38) and various 1,3-disubstituted uracils 4.121 (Scheme 39).

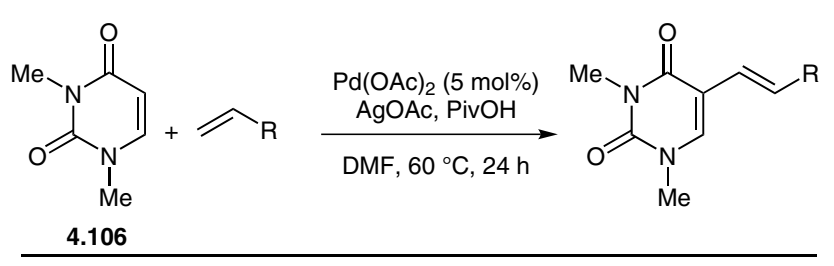<smiles>COn1c(=O)c(/C(C)=C/C(C)=O)cn(C)c1=O</smiles><smiles>Cn1cc(C2=CC(=O)C=CC2=O)c(=O)n(C)c1=O</smiles><smiles>C/C=C/c1cn(C)c(=O)n(C)c1=O</smiles>

4.118 $53 \%(\alpha / \beta=8.7: 1)$<smiles>Cn1cc(/C=C2\CCOC2=O)c(=O)n(C)c1=O</smiles><smiles>[Y6]n1cc(CC(=C)C(=O)OC(C)(C)C)c(=O)n(C)c1=O</smiles>

$$
96 \%(\alpha / \beta=1: 4.3)
$$

Scheme 38 Alkenylation of 1,3-dimethyluracil. Scope of the alkene component.

\subsection{Aerobic Alkenylation and its Application to the Synthesis of 1,3,5-Trisubstituted Ben- zenes}

Having developed a series of direct $\mathrm{C}-\mathrm{H}$ functionalizations of enaminones at the $\mathrm{C} 5$ position, we turned our attention to the use of molecular oxygen as a green and mild oxidant. ${ }^{37}$ Our previous methods required the use of stoichiometric amounts of heavy-metal or organometallic coupling partners, which was inconsistent with the original aim of $\mathrm{C}-\mathrm{H}$ functionalization.

We therefore explored some known biomimetic approaches to bypassing the high activation energy of mo- 
<smiles>[R]n1cc(/C=C/C(=O)OCC)c(=O)n([R7])c1=O</smiles><smiles>CCOC(=O)C=Cc1cn([Tl])c(=O)n([12CH])c1=O</smiles><smiles>Cc1cc(C)cc(Cn2c(=O)c(/C=C/C(=O)OC(C)(C)C)cn(Cc3ccccc3)c2=O)c1</smiles>

$R^{1}=R^{2}=\operatorname{Me}(4.107) 92 \%$

$=\operatorname{Bn}(\mathbf{4 . 1 2 2}) 94 \%$

$=\operatorname{MOM}(\mathbf{4 . 1 2 3}) 68 \%$

4.125

$=$ PMB (4.124) $96 \%$

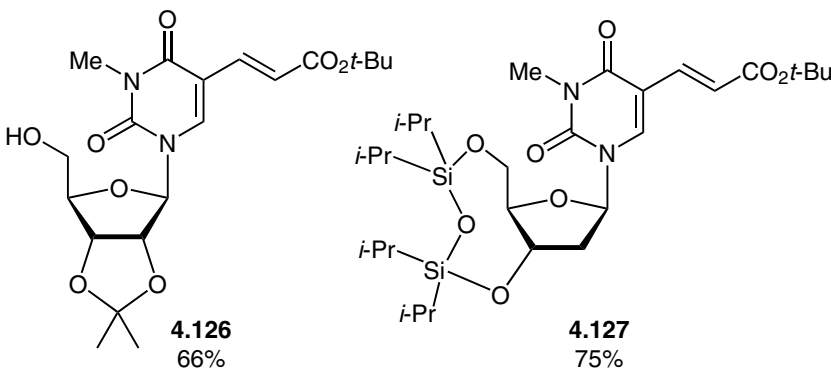

Scheme 39 Alkenylation reactions of various 1,3-disubstituted uracils with tert-butyl acrylate lecular oxygen. We found that a catalytic amount of catechol and copper(II) acetate effectively oxidized palladium, leading to multiple turnovers of the catalyst. Under optimized conditions, the coupling reactions of enaminones with alkenes proceeded smoothly under aerobic oxygen at room temperature in the presence of molecular sieves (Scheme 40).

Next, we attempted to convert the alkenylated products into the corresponding hydroquinolines by means of the Diels-Alder reaction. Unexpectedly, we obtained the trisubstituted benzenes 4.131-4.140 as the exclusive reaction products, presumably through a cascade sequence involving Diels-Alder reaction, aromatization, and retroMichael reaction (Scheme 41).

Although this outcome was unexpected, the products are nevertheless quite valuable because few general methods are currently available for synthesizing nonsymmetrical 1,3,5-substituted benzenes. Also, the products are highly electron-deficient in character and cannot, therefore, be synthesized efficiently by classical methods, such as electrophilic reactions. Finally, the products are chalcones, a group of compounds that are known to show a variety of biological effects, including antiinflammatory effects.

\begin{tabular}{|c|c|c|c|c|}
\hline & & & $\begin{array}{c}\mathrm{Pd}(\mathrm{TFA})_{2} \\
\mathrm{Cu}(\mathrm{OAc})_{2}, \text { catechol }\end{array}$ & alkenylated \\
\hline 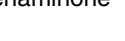 & + & alkene & $4 \AA \mathrm{MS}, \mathrm{DMF}$, r.t., $24 \mathrm{~h}$ & enaminone \\
\hline
\end{tabular}<smiles>[X]C=CC1=CN(Br)C([18OH])CC1=O</smiles>

$$
\begin{aligned}
\mathrm{X} & =\mathrm{CO}_{2} t-\mathrm{Bu}(\mathbf{4 . 8 0}) 89 \% \\
& =\mathrm{CO}_{2} \mathrm{Me}(\mathbf{4 . 8 1}) 78 \% \\
& =\mathrm{CO}_{2} n-\mathrm{Bu}(\mathbf{4 . 8 2}) 85 \% \\
& =\mathrm{CO}_{2} \mathrm{Bn}(\mathbf{4 . 8 3}) 87 \% \\
& =\mathrm{COMe}^{(4.84)} 69 \% \\
& =\mathrm{CONMe}(\mathbf{4 . 8 5}) 80 \% \\
& =\mathrm{P}(\mathrm{O})(\mathrm{OMe})_{2}(\mathbf{4 . 8 6}) 68 \% \\
& =\mathrm{Ph}(\mathbf{4 . 8 7}) 46 \%
\end{aligned}
$$<smiles>CC(=O)C=C(C)C1=CN(Cc2ccccc2)C([Y16]#N)CC1=O</smiles>

4.92<smiles>CC(C)(C)OC(=O)/C=C1/C=CN(Cc2ccccc2)C([Y6]#N)CC1=O</smiles>

4.129

$37 \%$

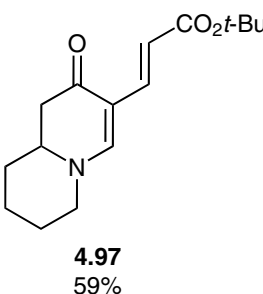

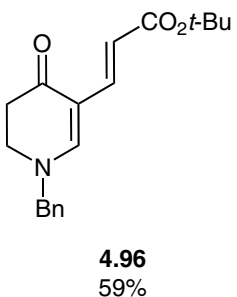

$59 \%$
$59 \%$<smiles>O=C1CC([Pb])C(=O)C=C1C=C1CCOC1=O</smiles>

4.128

$57 \%$<smiles>CCCC1CC(=O)C(/C=C/C(=O)OC(C)(C)C)=CN1Cc1ccccc1</smiles><smiles>O=C(/C=C/C1=CN(P)CCC1=O)O[Na]</smiles>

4.95

$32 \%$<smiles>CN1C=C(/C=C/C(=O)OC(C)(C)C)C([18OH])([18OH])C(=O)[C@@H]2CCCCC21</smiles>

Scheme 40 Scope of the aerobic alkenylation 
<smiles>C=CP(=O)(O)c1ccccc1</smiles>

$\mathrm{R}=\mathrm{SO}_{2} \mathrm{Me}(\mathbf{4 . 1 3 1}) 82 \%$<smiles>[R]c1cc(C(C)=O)cc(C(=O)C=C[PbH])c1</smiles>

$=\mathrm{COMe}$ (4.132) $66 \%$

$=\mathrm{CO}_{2} \mathrm{Me}(\mathbf{4 . 1 3 3}) 73 \%$

$=\mathrm{CO}_{2} n-\mathrm{Bu}(\mathbf{4 . 1 3 4}) 75 \%$

$=\mathrm{CO}_{2} \mathrm{Bn}(\mathbf{4 . 1 3 5}) 86 \%$

$=\mathrm{CN}(\mathbf{4 . 1 3 6}) 80 \%$

$=\mathrm{P}(\mathrm{O})(\mathrm{OMe})_{2}(4.137) 57 \%$

(based on rec. SM)<smiles>CC(=O)c1cc(C(=O)/C=C/P=O)cc2c1C(=O)NC2=O</smiles><smiles>N#Cc1cc(C(=O)C=C[Pb])cc(-c2ccccc2)c1</smiles><smiles>COC(=O)c1cc(C(=O)/C=C/P=N)cc(-c2ccccc2)c1</smiles>

4.139 $46 \%$

Although our main focus had been on the chemistry of enaminones 4.141, which can be readily converted into structurally diverse nitrogenous heterocyclic compounds, structural motifs such as $\mathbf{4 . 1 4 2}$ can also be found in a variety of bioactive compounds. We therefore began efforts to functionalize aminoenones of type 4.142. To this end, we turned our attention to the Knoevenagel reaction (Scheme 42). ${ }^{38}$

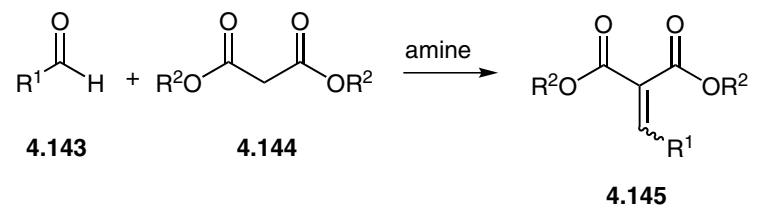<smiles>NC1=CC(=O)CCC1</smiles><smiles>[R]OC(=O)C(C(=O)O[R])C([R])C1=C(NP)CCCC1=O</smiles><smiles>[R]C(=O)C1C(=O)N(P)C2=C(C(=O)CCC2)C1[R]</smiles>

4.147

4.146 can be derived from in situ condensation 4.148

Scheme 42 Knoevenagel-type condensation of enaminones

We devised a novel variant of this reaction using paraformaldehyde (Scheme 43). Because of the reactivity of formaldehyde, the dimerization product $\mathbf{4 . 1 5 6}$, derived from condensation of the enaminone and formaldehyde, was obtained as the major product. This problem was overcome by increasing the rate of the initial reaction between formaldehyde and the reactive methylene (malonate) moiety by the addition of lithium perchlorate as a Lewis acid.

Under acidic conditions in the presence of trifluoroacetic acid, the products of the reaction cyclized to provide the bicyclic system $4.148\left(\mathrm{R}^{1}=\mathrm{H}\right)$ (Scheme 42). In addition, we found that triphenylphosphine catalyzed the reaction between enaminones and cyanoacetates to give the cyclized products directly (Scheme 44). The precise role of triphenylphosphine is obscure, but we assume that it is involved in both the Knoevenagel-type condensation and the cyclization steps. When a malonate was used instead of a cyanoacetate in this reaction, the desired product was not obtained. 
<smiles>[R]NC1=CC(=O)CC([R])C1</smiles><smiles>COC(C)CC1=C(NO)CCCC1=O</smiles><smiles>O=C1CCCC(NO)=C1CC(C(=O)O)C(=O)Br</smiles><smiles>O=C1CCCC(NN2CCOCC2)=C1CC(OCc1ccccc1)C(=O)OCc1ccccc1</smiles>
4.149 $90 \%$

$$
\begin{gathered}
4.150 \\
90 \%
\end{gathered}
$$$$
\begin{aligned}
& 4.151 \\
& 86 \%
\end{aligned}
$$<smiles>CC(=O)C(CC1=C(Nc2ccccc2)CC(C)(C)CC1=O)C(C)=O</smiles><smiles>CC(=O)CC(CC1=C(Nc2ccccc2)CCC1=O)C(C)=O</smiles>

4.152 $95 \%$

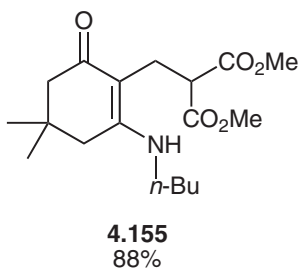

Scheme 43 Lithium perchlorate-assisted multicomponent reaction<smiles>[R6]OC(=O)CC#N</smiles><smiles>N#CC1CC2=C(CCCC2=O)N(CBr)C1=O</smiles><smiles></smiles><smiles>CCCCN1C(=O)C(C#N)CC2=C1CCCC2=O</smiles><smiles>CC(C)N1C(=O)C(C#N)CC2=C1CC(C)(C)CC2=O</smiles>

4.160

$75 \%$<smiles>COCCN1C(=O)C(C#N)CC2=C1CC(C)(C)CC2=O</smiles>

Scheme 44 Cascade reaction to form bicyclic systems

\section{$5 \quad$ Applications to Total Synthesis}

The development of the enaminone chemistry provided an opportunity to synthesize several indolizidine and quinolizidine alkaloids in a concise manner.

\subsection{Total Synthesis of (+)-Ipalbidine and (+)-An- tofine}

The enaminone chemistry was first applied to a synthesis of (+)-ipalbidine (5.5; Scheme 45), ${ }^{39}$ which is a nonaddictive analgesic, an oxygen-free radical scavenger, and an inhibitor of the respiratory burst of leukocytes. ${ }^{40-42}$ By using the ynone cyclization, we obtained enaminone $\mathbf{5 . 1}$ with an enantiomeric ratio of 98:2. This enaminone was subjected to the direct arylation protocol to give the arylated product 5.2. The arylated enaminone was reduced with L-selectride, and the resulting boron enolate was trapped with the Comins reagent $\{N-(5-$ chloro-2-pyridyl)bis[(trifluoromethane)sulfonimide $]\}$. The methyl group was then installed by Negishi coupling. Finally, the methyl group of the 4-methoxyphenyl substituent was removed by treatment with boron tribromide to give $(+)$-ipalbidine (5.5) with an enantiomeric ratio of 98:2, indicating that stereochemical integrity was retained throughout this synthetic process.

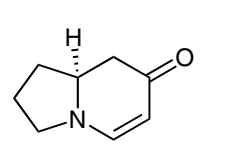

5.1

$e r=98: 2$<smiles>N#[Y16]C1=CN2CCC[C@@H]2CC1=O</smiles>

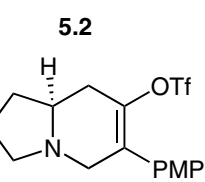

5.3

5.4<smiles>CC1=C([Nb])CN2CCC[C@H]2C1</smiles>

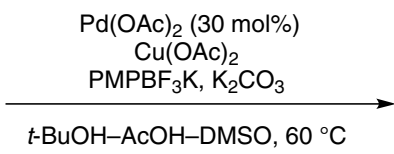

$70 \%$

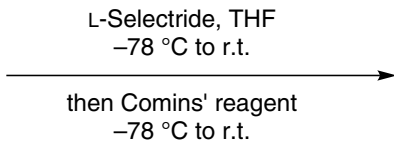

$76 \%$

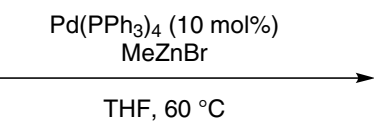

$91 \%$
Scheme 45 Synthesis of (+)-ipalbidine (5.5)

Having established a synthetic route to $(+)$-ipalbidine, we selected (+)-antofine (5.8) as our next target. ${ }^{39}$ Antofine exhibits low nanomolar antiproliferative activity against drug-sensitive and multidrug-resistant cancer cell lines, as well as antiviral activity. ${ }^{43-46}$ The $(+)$-antofine enantiomer 
was synthesized by subjecting triflate $\mathbf{5 . 3}$ to Negishi coupling with the arylzinc bromide $\mathbf{5 . 6}$ to give the biaryl product 5.7 (Scheme 46). This biaryl intermediate was oxidized with [bis(trifluoroacetoxy)iodo]benzene to give (+)-antofine (5.8). ${ }^{39}$<smiles>CCOC1=C([NH3+])CN2CCC[C@H]2C1</smiles>

5.3

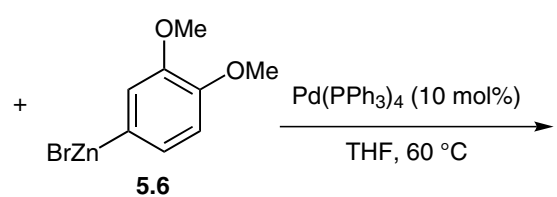

5.6<smiles>CCOC(=O)OCCOC(=O)OCC</smiles><smiles>COc1ccc2c3c(c4cc(OC)c(OC)cc4c2c1)C[C@@H]1CCCN1C3</smiles>

(+)-antofine (5.8)

Scheme 46 Synthesis of (+)-antofine (5.8)

\subsection{Total Synthesis of $(R)$ - and $(S)$-Boehmeriasin A}

We also succeeded in a synthesis of boehmeriasin A (5.14; Scheme 47), ${ }^{47}$ which had previously been isolated without assignment of its absolute stereochemistry. ${ }^{48}$ This compound was found to be more potent than paclitaxel in most cancer cell lines, with $\mathrm{GI}_{50}$ values ranging from 0.8 to $265 \mathrm{nM} .{ }^{49}$ Because the configuration of the stereocenter of boehmeriasin A was unknown at the time when we began our study, ${ }^{50}$ we synthesized both enantiomers of the compound.

We adopted a similar strategy to that which we used in our synthesis of ipalbidine, and we obtained triflate $\mathbf{5 . 1 2}$ in two steps from enaminone $\mathbf{5 . 9}$ (Scheme 47). Triflate $\mathbf{5 . 1 2}$ was subjected to Negishi coupling to provide the biarylamine 5.13, which was oxidized by using vanadyl trifluoride to give boehmeriasin A (5.14). The $(R)$ - and $(S)$ enantiomers were obtained in enantiomeric ratios of 97.5:2.5 and 98:2, respectively. By comparison with the literature, ${ }^{48,50}$ we confirmed that the $(R)$-product is the natural product.

Finally, we tested our synthetic compounds in three cancer cell lines, with paclitaxel as a control (Table 6). The $(R)$-enantiomer was more potent than the $(S)$-enantiomer and, most importantly, it showed activity in the taxolresistant cancer cell line NCI-ADR-RES.

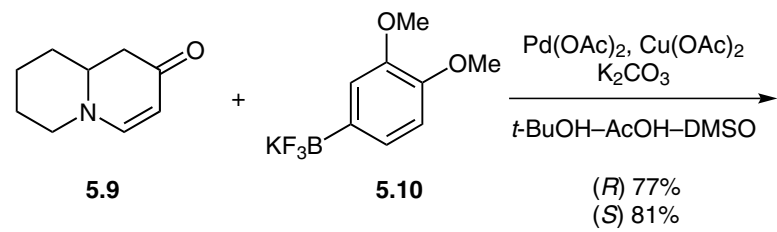<smiles>COc1ccc(C2=CN3CCCCC3CC2=O)cc1OC</smiles>

5.11

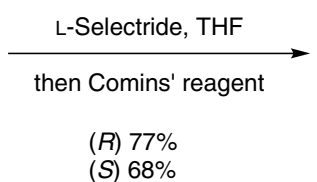

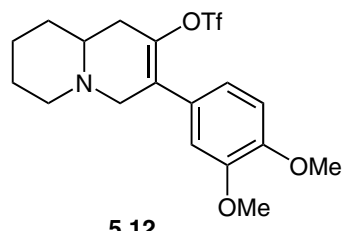

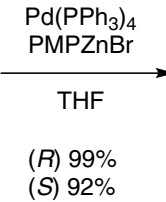

5.12<smiles>COc1ccc(C2=C(c3ccc(OC)c(OC)c3)CN3CCCCC3C2)cc1</smiles>

5.13<smiles>COc1ccc2c3c(c4cc(OC)c(OC)cc4c2c1)CN1CCCCC1C3</smiles>

(R) $74 \%$ er $=97.5: 2.5$

(S) $83 \%$, er $>98: 2$

Scheme 47 Synthesis of both enantiomers of boehmeriasin A

Table 6 Cytotoxicities of $(R)$ - and $(S)$-Boehmeriasin $\mathrm{A}^{47}$

\begin{tabular}{llll}
\hline Cell line & $\begin{array}{l}\mathrm{IC}_{50}(\mathrm{nM}) \\
\mathrm{COLO}-205\end{array}$ & MCF-7 & NCI-ADR-RES \\
\hline paclitaxel (control) & 3.31 & 1.62 & $>6400$ \\
$(R)$-boehmeriasin $\cdot \mathrm{HCl}$ & 4.18 & 43.4 & 36.7 \\
$(S)$-boehmeriasin $\cdot \mathrm{HCl}$ & 103 & 92.7 & 434 \\
\hline
\end{tabular}

\subsection{Total Synthesis of Tylocrebrine and Related Phenanthropiperidines}

Among the more than 60 known phenanthropiperidines, tylocrebrine (5.18, Scheme 48) is the only compound that has been tested in a clinical trial; however, this trial was terminated because patients experienced ataxia and disorientation, clearly indicating that the compound affects the central nervous system. Nevertheless, because of the 


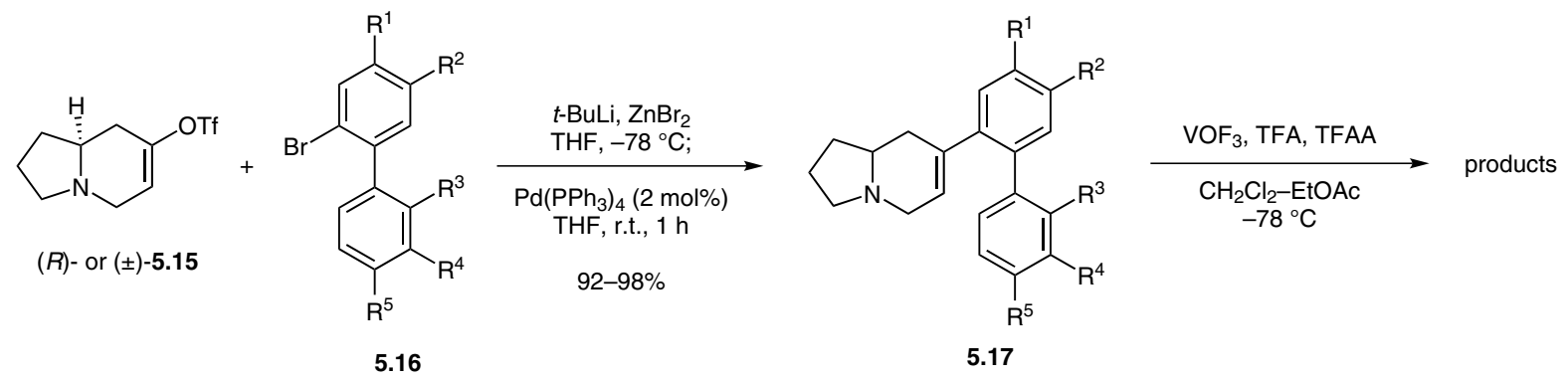<smiles>COc1cc2c3c(c4ccc(OC)c(OC)c4c2cc1OC)CN1CCCC1C3</smiles>

$(R)$ - and ( \pm )-tylocrebrine (5.18 $62 \%$<smiles>COc1cc2c3c(c4cc(OC)c(OC)cc4c2cc1OC)CN1CCCC1C3</smiles>

(R)- and ( \pm )-tylophorine (5.19) $89 \%$<smiles>COc1cc2c3c(c4cccc(OC)c4c2cc1OC)CN1CCCC1C3</smiles><smiles>COc1ccc2c3c(c4cc(OC)c(OC)cc4c2c1)CC1CCCN1C3</smiles>

antofine (5.8)<smiles>COc1ccc2c(c1)c1c(c3cc(OC)c(OC)cc32)CC2CCCN2C1</smiles><smiles>COc1ccc2c3c(c4cc(OC)c(OC)cc4c2c1)CN1CCCC1C3</smiles><smiles>COc1cc2c3c(c4ccccc4c2cc1OC)CC1CCCN1C3</smiles><smiles>COc1cc2c3c(c4ccccc4c2cc1OC)CN1CCCC1C3</smiles>

5.23

5.24

$85 \%$

Scheme 48 Synthesis of tylocrebrine (5.18) and related analogues

potency of tylocrebine, interest persists in developing phenanthropiperidines for chemotherapeutic purposes. In pursuit of developing a safe phenanthropiperidine as an anticancer agent, we embarked on the synthesis of tylocrebrine and several closely related analogues. ${ }^{51}$ The difficult problem of regioselectivity in the synthesis of tylocrebrine was solved by a unique disconnection that involved an aryl-alkene $\mathrm{C}-\mathrm{C}$ bond-forming reaction to construct the pentacyclic ring system.

As shown in Scheme 48, indolizidine triflate 5.15 was linked with a variety of biaryl groups by using a Negishi coupling; subsequent vanadyl trifluoride-mediated oxidative $\mathrm{C}-\mathrm{C}$ bond formation gave various phenanthroindolizidines 5.18-5.24. The aryl-alkene $\mathrm{C}-\mathrm{C}$ bond-forming reaction has few precedents in the literature.

The synthesized alkaloids were then tested against three cancer cell lines to evaluate their antiproliferative activities (Table 7). The alkaloids showed very potent cytotoxicities with broad spectra. The results show that removal or relocation of each of the methoxy groups affects the activity of the resulting analogue against NCI/ADR-RES, although most of the compounds remained potent against
COLO-205 and MCF-7, with the exception of compound 5.21 .

Table 7 Antiproliferative Activity of Phenanthroindolizidines ${ }^{51}$

\begin{tabular}{lccc}
\hline Cell line & $\begin{array}{l}\mathrm{IC}_{50}(\mathrm{nM}) \\
\mathrm{COLO}-205\end{array}$ & $\mathrm{MCF}-7$ & $\mathrm{NCI} /$ ADR-RES \\
\hline paclitaxel & 5.3 & 2.3 & $>6400$ \\
$(R)$-tylocrebrine & 1.3 & 15 & 26 \\
tylocrebrine & 12 & 39 & 46 \\
$(R)$-tylophorine & 17 & 32 & 160 \\
tylophorine & 10 & 42 & 50 \\
$\mathbf{5 . 2 0}$ & 9.5 & 22 & 16 \\
antofine & 2.8 & 21 & 23 \\
$\mathbf{5 . 2 1}$ & 270 & 530 & 1300 \\
$\mathbf{5 . 2 2}$ & 8.5 & 5.8 & 200 \\
$\mathbf{5 . 2 3}$ & 48 & 25 & 180 \\
$\mathbf{5 . 2 4}$ & 29 & 21 & 180 \\
\hline
\end{tabular}


We have shown that enaminones can be synthesized from amino acids in two complementary ways. Ynone cyclization provided a variety of enaminones, including sevenmembered azepinones, in a scalable manner. Although racemization occurred in some cases, the reaction was shown to proceed in the 6-endo-trig mode; this led to the identification of reaction conditions that minimized the racemization. The ynone cyclization enabled us to generate a quinolone library, to synthesize functionalized enaminones from $\beta$-lactams, and to obtain unique sevenmembered 3,4-dihydro-1,2-oxazepin-5(2H)-ones.

The ketene cyclization gave enantiopure enaminones carrying carbonyl groups at the C5 position that can as handles for further functionalization. The use of diazomethane limited the scale and applicability of this reaction, a shortcoming that prompted us to develop a threecomponent strategy for synthesizing enaminones in a simple manner. Note that this ketene cyclization represents a rare example of a case in which a carbon nucleophile is used to react with a ketene electrophile.

Considerable efforts were also devoted to the development of C5 functionalization. Inspired by direct arylation using aryl(trifluoro)borates, we developed several superior or complementary protocols. A Suzuki-type coupling with boronic acids was found to be general and of wide scope for $\mathrm{C} 5$ arylation of enaminones, presumably as a result of the neutral reaction conditions and the use of copper additives to facilitate transmetalation. A Hiyama-type coupling with silicon reagents was developed as a complementary method. The conditions for Heck-type coupling were also investigated, leading to the alkenylation of enaminones and uracils by using the Fujiwara-Moritani reaction conditions.

After we had developed the synthetic methods and the various derivatization strategies, we applied our enaminone chemistry in syntheses of several phenanthropiperidine natural products.

Since we first reported our enaminone chemistry in 2006, we have been fascinated by the exceptional versatility and utility of enaminones. Not only did we enjoy developing new synthetic methods and derivatizations, but we were also pleased to discover that the resulting enaminones provide unique opportunities for synthesizing biologically active compounds, which significantly broadened the scope of our research.

\section{Acknowledgment}

This work was supported by grants from the National Institutes of Health (CA90602, GM069663, GM076302, GM081267) and by the University of Minnesota through the Vince and McKnight Endowed Chairs. The authors thank Dr. Brandon J. Turunen, Dr. Haibo Ge, Dr. Micah J. Niphakis, Dr. Matthew W. Leighty, Dr. Antonella Pepe, Dr. Sanjay Molhotra's group at the NCI, Dr. Timothy R. Ward, Dr. Torsten Haack, William Shadrick, Dr. Xiangian Gu,
Dr. Lei Bi, Dr. Yiyun Yu, Dr. Yong Wook Kim, and Dr. Adwait R. Ranade for their contributions to the enaminone chemistry.

\section{References}

(1) Michael, J. P. Nat. Prod. Rep. 2008, 25, 139.

(2) Chemler, S. R. Curr. Bioact. Compd. 2009, 5, 2.

(3) Joseph, S.; Comins, D. L. Curr. Opin. Drug Discovery Dev. 2002, 5,870

(4) Comins, D. L.; Joseph, S. P. Adv. Nitrogen Heterocycl. 1996, 2, 251.

(5) Hickmott, P. W. Tetrahedron 1982, 38, 3363.

(6) Hickmott, P. W. Tetrahedron 1982, 38, 1975.

(7) Alawar, R. S.; Joseph, S. P.; Comins, D. L. Tetrahedron Lett. 1992, 33, 7635.

(8) Comins, D. L.; Zeller, E. Tetrahedron Lett. 1991, 32, 5889.

(9) Comins, D. L.; Killpack, M. O. J. Am. Chem. Soc. 1992, 114, 10972.

(10) Comins, D. L.; Joseph, S. P.; Chen, X. Tetrahedron Lett. 1995, 36, 9141.

(11) Kranke, B.; Kunz, H. Org. Biomol. Chem. 2007, 5, 349.

(12) Comins, D. L.; Morgan, L. A. Tetrahedron Lett. 1991, 32, 5919.

(13) Klegraf, E.; Knauer, S.; Kunz, H. Angew. Chem. Int. Ed. 2006, 45, 2623.

(14) Knauer, S.; Kunz, H. Tetrahedron: Asymmetry 2005, 16, 529.

(15) Turunen, B. J.; Georg, G. I. J. Am. Chem. Soc. 2006, 128, 8702.

(16) Niphakis, M. J.; Turunen, B. I.; Georg, G. I. J. Org. Chem. 2010, 75, 6793.

(17) Ward, T. R.; Turunen, B. J.; Haack, T.; Neuenswander, B Shadrick, W.; Georg, G. I. Tetrahedron Lett. 2009, 50, 6494.

(18) Pepe, A.; Pamment, M.; Georg, G. I.; Malhotra, S. V. J. Org. Chem. 2011, 76, 3527.

(19) Pepe, A.; Pamment, M.; Kim, Y. S.; Lee, S.; Lee, M.-J.; Beebe, K.; Filikov, A.; Neckers, L.; Trepel, J. B.; Malhotra, S. V. J. Med. Chem. 2013, 56, 8280.

(20) Ranade, A. R.; Georg, G. I. J. Org. Chem. 2014, 79, 984

(21) Chen, Y.; Yoshida, M.; MacMillan, D. W. C. J. Am. Chem. Soc. 2006, 128, 9328.

(22) Seki, H.; Georg, G. I. J. Am. Chem. Soc. 2010, 132, 15512.

(23) Enantioselective Synthesis of $\beta$-Amino Acids; Juaristi, E., Ed.; Wiley-VCH: New York, 1997.

(24) Seki, H.; Georg, G. I. Org. Lett. 2011, 13, 2147.

(25) Wang, X.; Turunen, B. J.; Leighty, M. W.; Georg, G. I. Tetrahedron Lett. 2007, 48, 8811.

(26) Ge, H. B.; Niphakis, M. J.; Georg, G. I. J. Am. Chem. Soc. 2008, 130, 3708.

(27) Kim, Y. W.; Niphakis, M. J.; Georg, G. I. J. Org. Chem. 2012, 77, 9496.

(28) Bi, L.; Georg, G. I. Org. Lett. 2011, 13, 5413.

(29) Yu, Y.-Y.; Bi, L.; Georg, G. I. J. Org. Chem. 2013, 78, 6163.

(30) Yu, Y.-Y.; Niphakis, M. J.; Georg, G. I. Org. Lett. 2011, 13, 5932.

(31) Moritani, I.; Fujiwara, Y. Tetrahedron Lett. 1967, 1119.

(32) Fujiwara, Y.; Moritani, I.; Matsuda, M.; Teranish, S. Tetrahedron Lett. 1968, 3863.

(33) Fujiwara, Y.; Moritani, I.; Danno, S.; Asano, R.; Teranish, S. J. Am. Chem. Soc. 1969, 91, 7166.

(34) Yu, Y.-Y.; Georg, G. I. Chem. Commun. 2013, 49, 3694.

(35) González Moa, M. J.; Besada, P.; Terán, C. Synthesis 2006, 3973.

(36) Roh, K. R.; Kim, J. Y.; Kim, Y. H. Tetrahedron Lett. 1999 , 40, 1903.

(37) Yu, Y.-Y.; Georg, G. I. Adv. Synth. Catal. 2014, 356, 1359.

(38) Gu, X.; Georg, G. I. Tetrahedron 2013, 69, 9406. 
(39) Niphakis, M. J.; Georg, G. I. J. Org. Chem. 2010, 75, 6019.

(40) Wang, L. M.; Chu, Y. H. Yaoxue Xuebao 1996, 31, 806.

(41) Chen, X.; Chu, Y. Zhongguo Yaolixue Tongbao 1998, 14, 243.

(42) Chen, X.; Chu, Y.; Han, G. Zhongguo Yaolixue Tongbao 1998, 14, 167.

(43) Gao, W.; Chen, A. P.-C.; Leung, C.-H.; Gullen, E. A.; Fürstner, A.; Shi, Q.; Wei, L.; Lee, K.-H.; Cheng, Y.-C. Bioorg. Med. Chem. Lett. 2008, 18, 704.

(44) Lee, S. K.; Nam, K.-A.; Heo, Y.-H. Planta Med. 2003, 69, 21.

(45) Fu, Y.; Lee, S. K.; Min, H.-Y.; Lee, T.; Lee, J.; Cheng, M.; Kim, S. Bioorg. Med. Chem. Lett. 2007, 17, 97.
(46) Wang, K.; Su, B.; Wang, Z.; Wu, M.; Li, Z.; Hu, Y.; Fan, Z.; Mi, N.; Wang, Q. J. Agric. Food Chem. 2010, 58, 2703.

(47) Leighty, M. W.; Georg, G. I. ACS Med. Chem. Lett. 2011, 2, 313.

(48) Luo, Y.; Liu, Y.; Luo, D.; Gao, X.; Li, B.; Zhang, G. Planta Med. 2003, 69, 842.

(49) Yan, J.; Luo, D.; Luo, Y.; Gao, X.; Zhang, G. Int. J. Gynecol. Cancer 2006, 16, 165.

(50) Dumoulin, D.; Lebrun, S.; Couture, A.; Deniau, E.; Grandclaudon, P. Eur. J. Org. Chem. 2010, 1943.

(51) Niphakis, M. J.; Georg, G. I. Org. Lett. 2011, 13, 196. 